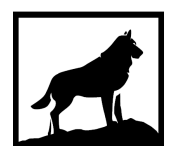

1885

Michigan

\title{
AN INVESTIGATION OF A FOREST FIELD TRIP FOR \\ ELELMENTARY STUDENTS: WHAT STRATEGIES WERE USED, AND TO WHAT EXTENT WERE THESE STRATEGIES EFFECTIVE IN SUPPORTING STUDENT LEARNING?
}

Michelle M. Miller

Michigan Technological University, michellem@mtu.edu

Copyright 2016 Michelle M. Miller

Recommended Citation

Miller, Michelle M., "AN INVESTIGATION OF A FOREST FIELD TRIP FOR ELELMENTARY STUDENTS: WHAT STRATEGIES WERE USED, AND TO WHAT EXTENT WERE THESE STRATEGIES EFFECTIVE IN SUPPORTING STUDENT LEARNING?", Open Access Master's Report, Michigan Technological University, 2016.

https://doi.org/10.37099/mtu.dc.etdr/285

Follow this and additional works at: https://digitalcommons.mtu.edu/etdr

Part of the Educational Assessment, Evaluation, and Research Commons 


\title{
AN INVESTIGATION OF A FOREST FIELD TRIP FOR ELELMENTARY STUDENTS: WHAT STRATEGIES WERE USED, AND TO WHAT EXTENT WERE THESE STRATEGIES EFFECTIVE IN SUPPORTING STUDENT LEARNING?
}

\author{
By \\ Michelle M. Miller
}

\author{
A REPORT \\ Submitted in partial fulfillment of the requirements for the degree of \\ MASTER OF SCIENCE \\ In Applied Science Education \\ MICHIGAN TECHNOLOGICAL UNIVERSITY \\ 2016
}

(C) 2016 Michelle M. Miller 
This report has been approved in partial fulfillment of the requirements for the Degree of MASTER OF SCIENCE in Applied Science Education.

Department of Cognitive and Learning Sciences

\section{Report Advisor: Kedmon Hungwe}

Committee Member: $\quad$ Alexandria Guth

Committee Member: Amy Lark

Department Chair: Susan Amato-Henderson 
This report is dedicated to Joan Chadde.

Her devotion to environmental education has inspired me. 


\section{Table of Contents}

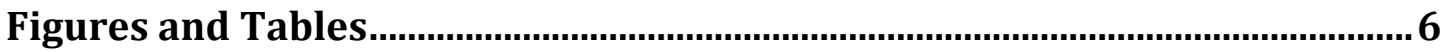

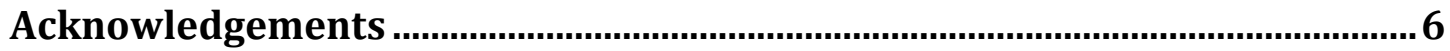

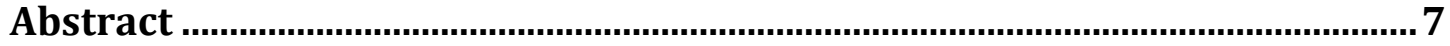

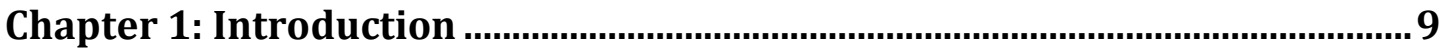

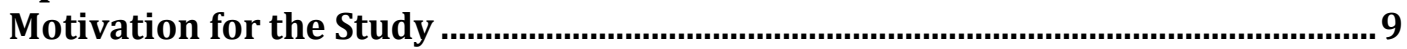

Research Questions .........................................................................................10

Context of the Study ............................................................................................11

Hypotheses..................................................................................................12

The Activities and Science Standards.................................................................... 13

Chapter 2: Literature Review.......................................................................... 14

Environmental Education in Schools.................................................................... 14

Outdoor Programming Terminology .................................................................. 14

Strategies for Conducting Forest-Based Programs ……….................................... 16

Assessing Outdoor Learning Programs ................................................................17

The Challenges Associated with Outdoor Field Trips in Schools ............................ 18

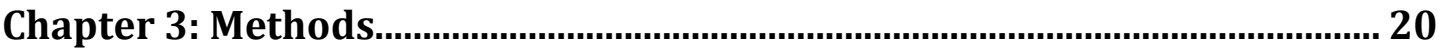

Prior to the Study: The Pilot Program ……….................................................... 20

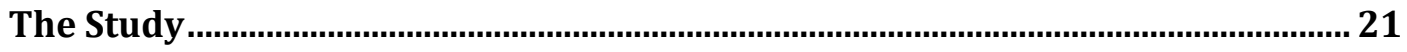

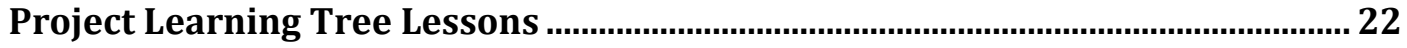

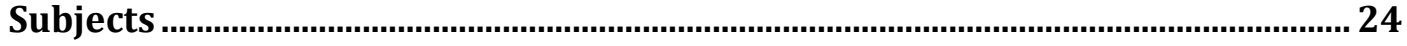

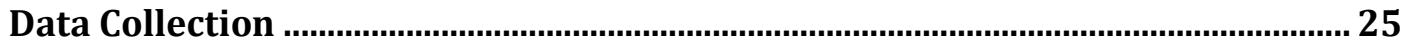

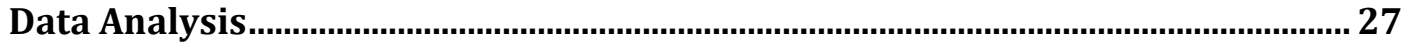

Summary of Each Group........................................................................................ 28

Chapter 4: Results and Discussion ................................................................. 33

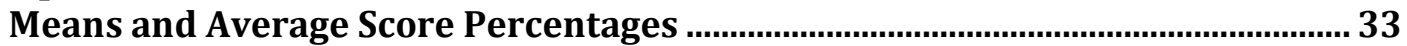

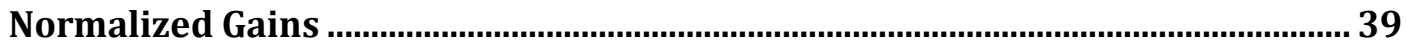

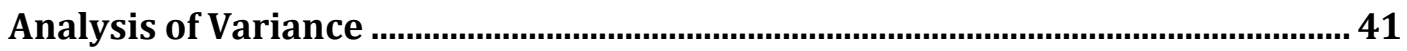

Teacher Evaluations .................................................................................................... 44

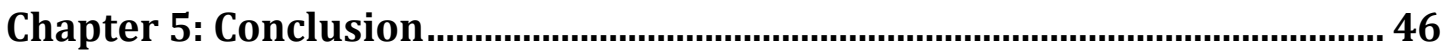

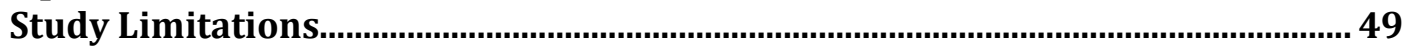

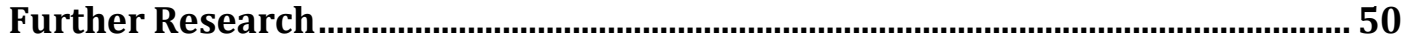

References .................................................................................................... 51

Appendix A: Outdoor Science Investigations brochure................................... 54

Appendix B: Michigan Science Grade Level Content Expections .................... 56

Appendix C: Wheels to Woods! Application....................................................58

Appendix E: Permission Slip Required for Student Participation ................. 64

Appendix F: Pre- and Posttest, Grading Rubric and Test Samples ................ 65

Appendix G: Teacher Survey Administered by Google Forms........................ 74 
Figures

Figure 1: An Illustration Showing Opposite Branching .......... 27

Figure 2: Average Normalized Gain Equation ......................40

\section{Tables}

Table 1: Student Participants and Tests Taken ...................... 24

Table 2: Pre- and Posttest Mean Scores ..............................34

Table 3: Pretest Average Score Percentage for Each Grade .... 36

Table 4: Posttest Average Score Percentage for Each Grade .. 37

Table 5: Average Gain Percentages for Each Grade................38

Table 6: Average Normalized Gain for Each Grade ...............40

Table 7: Single-Factor ANOVA Test for Pretest Scores ........... 41

Table 8: Single-Factor ANOVA test for Posttest Scores........... 42 


\section{Acknowledgements}

I would like to extend my gratitude to the many who have made this journey possible.

Thank you to my family, who have been supportive every step of the way. To my husband, Justin for encouraging me to pursue this degree and for adjusting his busy schedule to accommodate mine. To all of my family and friends who helped with childcare while I attended classes or worked on my research.

Thank you to my committee. To Kedmon Hungwe, for serving as my advisor. His guidance throughout this process was imperative to my success. To Alexandria Guth for serving on my committee. I also appreciate her diligence in reading through my report and found her suggestions to be very helpful. To Amy Lark for serving on my committee despite her busy schedule. Her comments during my defense added depth to this report.

I would also like to thank Mike Smalligan and the Michigan DNR, for the Forest Stewardship grant that provided transportation reimbursement to the participating schools. Thank you to the $\mathrm{K}-5^{\text {th }}$ grade teachers and students at the Chassell Township Schools for their participation in the pilot study and to the $3^{\text {rd }}-5^{\text {th }}$ grade teachers and students at the Luther L. Wright School for their participation in this study. 


\section{Abstract}

Many times when field experiences occur with elementary students there is no assessment of the programming, and therefore no data showing how the participants' learning was impacted. This study focuses on the effectiveness of a forest field trip offered to $3^{\text {rd }} 5^{\text {th }}$ grade students at a public school in Gogebic County, Michigan.

The study was guided by the following research questions:

- What strategies have been used to conduct forest-based environmental education programs in the Western Upper Peninsula?

- What has been the impact of the strategies on students' environmental knowledge?

- In what ways if any, can the conduct of the learning experiences be improved?

The students participated in a 1.5-hour field trip that included experiential, environmental science activities at a nearby forest. To assess the participants' environmental knowledge, pre- and posttests were administered. Prior to participating in the program the students completed a one-page, three-part pretest based on the content that would be covered during the field trip. The activities were developed from three different lessons found in the Project Learning Tree curriculum guide (American Forest Foundation, 2007). Each activity was about 20-30 minutes long. 
The students completed the posttest immediately following the field trip experience. The results were analyzed by class and grade to determine if there were changes after participation in the programming. Teachers were also given an evaluation to determine what strategies are most effective in making outdoor field trips possible for students.

The results did show statistically significant gains in the test scores, with some of the questions showing higher gains than others. The $5^{\text {th }}$ grade students had the highest gains between the pre- and posttest scores. The teacher evaluations showed that teachers would be more likely to participate in an outdoor field trip if transportation reimbursements were available and if a natural resource professional was present to lead the programming. These findings may be of interest to educators and other personnel interested in using forest field trips as a way of supporting student learning. 


\section{Chapter 1: Introduction}

\section{Motivation for the Study}

I was employed at the Western Upper Peninsula Center for Science, Mathematics and Environmental Sciences (Western UP Center) from 20092013, where one of my main duties was coordinating the Outdoor Science Investigations program. This involved developing, scheduling and conducting outdoor field trips for classes throughout the five counties in the Western Upper Peninsula. During my employment I conducted over 500 field trips, most being 1.5 hours in length, to students in preschool through high school, with the majority of the field trips being for students in $\mathrm{K}-5^{\text {th }}$ grade. They occurred during the school day, with the teacher present. Teachers were sent an evaluation after the field trip to provide feedback that was used to help in improving the program and to make sure that we were meeting teachers' needs as much as possible. Due to time and logistical constraints, the Western UP Center does not administer any student assessments of the Outdoor Science Investigations. For my research I wanted to implement forest field trips similar to those offered through the Western UP Center's Outdoor Science Investigations program, and assess the student learning outcomes along with other factors associated with this outdoor learning experience. 
In the fall of 2009, I attended a conference where Dr. Denise Mitten, Chair of the PhD in Sustainability Education at Prescott College, spoke on the many benefits of outdoor experiences for both children and adults. At the end of her presentation she mentioned various ways that we can make a difference in providing students with more opportunities for outdoor learning. She stressed the importance of continued research exploring the effectiveness of outdoor experiential learning opportunities. My study will contribute towards the research of similar outdoor programming.

\section{Research Questions}

This study aimed to answer the following three question:

- What strategies have been used to conduct forest-based environmental education programs in the Western Upper Peninsula?

- What has been the impact of the strategies on students' environmental knowledge?

- In what ways if any, can the conduct of the learning experiences be improved? 


\section{Context of the Study}

The Outdoor Science Investigations program was developed in 2001, and is largely supported through grant funding (Western UP Center, 2015). The field trips are offered each fall, winter and spring, and with each season two topics are offered for each class. All of the field trips include activities that align to the Science Grade Level Content Expectations. A sample brochure from the Outdoor Science Investigations program can be found in Appendix A.

Many teachers consistently sign their classes up for the Outdoor Science Investigations and have come to rely on the activities as a way to supplement the teaching that they do in the classroom. These field trips can be an effective way to enhance conceptual knowledge, in addition to providing other benefits, such as giving students a greater appreciation for the natural world and facilitating an opportunity for exploration and discovery (Bogner, 1998). The Outdoor Science Investigations program is well-received by students as well as teachers. From my observations, the students are eager for the opportunity to learn in an outdoor setting through the hands-on experiences. 


\section{Hypotheses}

Prior to conducting the research, I developed the following hypotheses:

1. Outdoor learning experiences have the potential to enhance conceptual knowledge of elementary school students.

There are times when a teacher would like to participate in an outdoor field trip, but cannot justify the experience, to themselves or someone else such as an administrator, due to financial constraints, curriculum obligations, or scheduling difficulties (Yunker, 2011). Having data that shows the impacts of these experiences, may place a higher value on outdoor field trip experiences.

2. Knowledge is gained during outdoor learning experience despite the less controlled setting.

When students are in an outdoor setting and are actively exploring or making new discoveries, the learning atmosphere is much different than that of students quietly sitting at their desks in their classroom. These real life, experiential learning opportunities can be an effective in promoting learning and developing higher order thinking skills (Behrendt \& Franklin, 2014).

3. The $5^{\text {th }}$ grade will have the highest test scores and gains and the $3^{\text {rd }}$ grade will have the lowest.

The $3^{\text {rd }} 5^{\text {th }}$ grade students in this study all took the same pre- and posttest and participated in the same activities. According to Piaget's developmental theory, the older students should gain more, especially on items requiring higher order thinking skills (Powell \& Kalina, 2009). 


\section{The Activities and Science Standards}

The lessons were chosen from Project Learning Tree's Pre K-8 Environmental Education Activity Guide. This guide, developed by the American Forest Foundation, is one of the most commonly used environmental education programs in the United States (American Forest Foundation, 2016). I chose this curriculum to enhance validity. Project Learning Tree:

- was developed in the mid-70's.

- activities are aligned to state and national academic standards

- has been researched and determined to be an effective learning tool I chose activities from three different lessons: We All Need Trees, Name That Tree, and Tree Cookies. The activities are described in more detail in Chapter 3. The Michigan Science Grade Level Content Expectations that are aligned to each of the three activities used in this study are included in Appendix B. 


\section{Chapter 2: Literature Review}

\section{Environmental Education in Schools}

In the past decade there has been a strong movement, led in part by the No Child Left Inside Coalition, to support schools in providing more environmental science education (EE) in schools. The Coalition was formed in 2007, to alert Congress and the public to the importance of EE for our children (No Child Left Inside Coalition, 2016), which was at the time declining from schools after being replaced by more highly valued math and reading programs. In attempts to "close the achievement gap", environmental education was limited or completely absent from many United States schools (Gruenewald \& Manteaw, 2007). The No Child Left Behind law passed by the federal government in 2001, was amended by the No Child Left Inside Act in 2011 to incorporate EE curriculum. Since this time, more emphasis has been placed on environmental literacy and EE programming, but according to Gruenewald \& Manteaw (2007), it continues to be marginalized, misunderstood, or completely lacking in many schools.

\section{Outdoor Programming Terminology}

Field trips allow students to explore a unique area outside of the classroom (Behrendt \& Franklin, 2014), but in some instances field trips are seen as "extra-curricular" opportunities (Yunker, 2011). Therefore, calling the program a "science investigation" rather than a field trip may encourage greater participation. 
Other educational movements that may overlap or parallel the programming include: Place-Based Education (Powers, 2004), SchoolyardEnhanced Learning (Broda, 2007), Outdoor Education (Adkins \& Simmons, 2002) and Environmental Education (Gruenewald \& Manteaw, 2007). All of these educational movements, though differing slightly by definition, typically have components that include outdoor learning.

Numerous studies show an increase in environmental knowledge after an outdoor experience (Bogner, 1998, Carrier, 2009). In addition to environmental knowledge, research has shown a wide range of benefits to outdoor learning including increased perception and vocabulary, and a greater appreciation for the outdoors (Behrendt \& Franklin, 2014), increased positive environmental attitudes and behaviors (Wells \& Lekies, 2006) and a stronger "sense of place" (Haywood, 2014). Research also reports health benefits such as a decrease in attention deficit disorder symptoms (Faber Taylor \& Kuo 2008). The program conducted for this study was called a Forest Field Trip. The outdoors would be the context or location for the program, experiential learning would be the process, and concepts learned were related to environmental science (Carrier, 2009). 


\section{Strategies for Conducting Forest-Based Programs}

Project Learning Tree, a program of the American Forest Foundation, has been dedicated to advancing environmental literacy and stewardship since the mid-7o's (American Forest Foundation, 2016). The Project Learning Tree curriculum and professional development is available to teachers throughout the country. In Michigan, Project Learning Tree is coordinated by the Michigan Department of Natural Resources (Michigan DNR). Project WET is another curriculum that focuses on environmental and ecological issues related to water (Project Wet Foundation, 2011). These hands-on lessons have also been shown to be effective in engaging students and successfully increasing knowledge (Powell \& Wells, 2002).

Teachers undertaking outdoor learning activities must be prepared for the experience, and must also prepare the students for this change in venue. It is important that the students know what is expected of them and are given clear boundaries. They should also be given the freedom for exploration and discovery during the outdoor experience (Behrendt \& Franklin, 2014). Students should have frequent local outdoor learning opportunities to decrease the novelty and improve their focus on learning (Randler, Ilg \& Kern, 2005). This was something I witnessed first-hand when coordinating the Outdoor Science Investigations program. The classes that participated in outdoor learning on a regular basis were more familiar with the expectations during the activities and therefore needed less prompting, had minimal management issues and experienced smooth transitions throughout the programming. 
Having a familiar forested site at or nearby the school would make forest-based programming feasible for a higher number of teachers (Broda, 2007). Another strategy is to bring the students to a location such as a nature center, where a natural resource professional could lead the programming (Meichtry \& Harrell, 2002).

The Wheels to Woods! Fund (American Tree Farm System, 2016), which began in the 2015-2016 school year, provides grant money to reimburse schools for transportation costs associated with forest field trips. The program is a partnership between the Michigan DNR, Michigan Forest Products Council and the Michigan Tree Farm Committee. A Wheels to Woods! application is included in Appendix C. Programs that offer transportation reimbursement such as this make forest field trips more feasible for many teachers (Yunker, 2011).

\section{Assessing Outdoor Learning Programs}

Various assessment tools have been used to evaluate Environmental Education programming, but many need further research to validate their effectiveness (Kyung-Ok 2003). SOLEI, The Science Outdoor Learning Environment Inventory, is one tool that has been used for assessment of seven different components of outdoor learning (Orion, Hofstein, Tamir and Giddigs, 1997). Of these seven components, which include factors such as open-endedness, student cohesiveness, and environmental interaction, none include information about the knowledge gained. 
The Children's Environmental Attitude and Knowledge Scale (CHEAKS) was found to be highly reliable for students up to Grade 7 (Leeming, Porter, Dwyer and Bracken, 1995). This 66-question, multiplechoice assessment tool does have a component that measures knowledge, but the 30 questions are related to general environmental knowledge and not associated with any particular curriculum. Findings from a study evaluating the validity of the CHEAKS assessment tool for students averaging 16 years of age found differences in the knowledge scores based on age, but not on the attitude scores (Walsh-Daneshmandi and MacLachlan, 2006).

When reviewing literature, I was unable to find any standardized tool that has been developed to measure the knowledge gained after participation in a specific curriculum appropriate for use in an outdoor learning program and therefore created my own instrument to test knowledge.

\section{The Challenges Associated with Outdoor Field Trips in Schools}

Many teachers place a high value on outdoor learning experiences, but their students receive very few opportunities for learning activities occurring outside of the classroom (Bierle \& Singletary, 2008). This inconsistency may be due to various challenges that teachers face regarding outdoor learning, some discussed in the following paragraphs. Lack of transportation and funding is stated in numerous research studies as a major factor in preventing teachers from taking their students on outdoor field trips beyond the schoolyard (Behrendt \& Franklin 2014, Meichtry \& Harrell 2002, Michie 1998). 
Recent research by Yunker (2011) involved interviewing a teacher and administrator regarding challenges associated with outdoor learning experiences that take place away from the school. Financial barriers were mentioned numerous times as one of the major challenges.

Research has also identified the focus on teaching to and meeting standards to be a challenge in implementing outdoor learning. The administrator stated that in order for teachers to be approved for a field trip it must be tightly aligned to the curriculum they are required to teach (Yunker, 2011). Another factor is a perceived lack of knowledge involving outdoor instruction, both with the content and the setting is prevalent among many teachers (Yunker, 2011). A teacher need assessment in Kentucky identified curriculum and lessons as the second-highest need, following funding (Meichtry \& Harrell, 2002). Other challenges include scheduling issues, lack of administrator support and poor behavior or attitudes from students (Michie, 1998). 


\section{Chapter 3: Methods}

Prior to the Study: The Pilot Program

Before conducting the field trips with the Gogebic County students, I ran a pilot program with Kindergarten $-5^{\text {th }}$ grade students from a Houghton County school. There were some slight differences in this program compared to the field trips held for the students in Gogebic County. All of the K-5 $5^{\text {th }}$ grade students from the Houghton County School were bussed to the Ford Forestry Center to participate in the field trip at the same time. Having this many students at one time required the program to be set up in stations, where each class visited four different stations, led by four different presenters. There was also time allocated for the students to eat lunch and to have a teacher-led session of free-time. The $3^{\text {rd }}-5^{\text {th }}$ grade students were assessed using the pre- and posttest I had developed. Each teacher administered these tests with their students in the classroom, before and after the field trip.

The trial run helped to identify a few areas that could be improved. After conducting the field trips with the Houghton County School I decided to personally administer the pre- and posttests in an effort to create as much consistency as possible for each class. Even though I specified to the Houghton County teachers to have the students answer the questions on their own, this varied between classes. All of the students took the test individually, but some of the students ended up telling the others the answers during the tests and some of the teachers gave hints when the students asked questions. 
There was also a question on the test that I decided to reword after analyzing the completed tests from the pilot study. On Question 1, "apple" was listed as a possible product we use that comes from trees. When asked to list which part of the tree it comes from, many wrote "branches" when "fruit" was the correct answer. I changed the choice from "apple" to "applesauce", which is also a better representation of something produced from trees.

Due to the logistics of the program for the Houghton County students, I needed other presenters to assist with the activities. I provided the other presenters with a detailed lesson plan to follow. After discussion with the presenters following the program I determined that they were not consistent in their delivery of the activities between groups and for a few of the groups did not cover the content that was included on the pre- and posttest. I therefore decided to be the sole person conducting the field trips for my study.

\section{The Study}

The study focused on the effectiveness of an outdoor forest field trip program offered to $3^{\text {rd }}-5^{\text {th }}$ grade students at a public school in Gogebic County, Michigan. Transportation cost is one of the obstacles that teachers face when they want to take their students on a field trip any distance from the school (Behrendt \& Franklin, 2014, Meichtry \& Harrell, 2002, Michie 1998, Yunker, 2011). To encourage participation in my study, I acquired a Forest Stewardship Grant from the Michigan DNR. The grant provided reimbursement to the schools for the transportation costs associated with the participation of these field trips. 
The site chosen for this study was Lost Lake, which is on property owned by the Charter Township of Ironwood and located about 10 miles from the school. The forest is managed by Green Timber Consulting Foresters, Inc. and recently the Charter Township of Ironwood board of commissioners expressed to the forestry firm an interest in having their property used for outreach and education by the local students.

The site included a small pavilion with about six picnic tables in it, one portable latrine, and an open area surrounding the lake. The surrounding forested area included various sized trees of about eight different species. When the students first arrived they spent a few minutes completing the onepage pretest. The students then participated in three activities, each about 20 minutes long, and prior to them leaving I administered the posttest.

\section{Project Learning Tree Lessons}

Three lessons from Project Learning Tree's Pre K-8 Environmental Education Activity Guide were used as guidelines for the three activities that the students participated in. I determined that adapting my activities from these lessons would add validity to the study as well as make it easier to build upon, should someone be interested in expanding on this research. Below is a synopsis of the three activities that were used. Appendix B includes the Science Grade Level Content Expectations for $3^{\text {rd }}-5^{\text {th }}$ grade that each activity aligns to. The rationale for each lesson is provided, based on citations from the Pre K-8 Environmental Education Activity Guide. 


\section{Lesson 13: We All Need Trees}

Objective: Students examined various products and determined which were made from trees and what part of the tree they came from.

"Students are often surprised to learn how many different products we get from trees. This activity helps students learn just how much we depend on trees in our daily lives." (PreK-8 Environmental Education Activity Guide, p.65)

\section{Lesson 68: Name That Tree}

Objective: Students will identify several trees using various physical characteristics.

"Tree species can be identified by looking at several different features. In this activity students will learn more about trees through these identifying features." (PreK-8 Environmental Education Activity Guide, p.288)

\section{Lesson 76: Tree Cookies}

Objective: Students will examine cross-sections of trees. "The way to learn about tree growth is to look at annual rings. Tree rings show patterns of change in a tree's life" (PreK-8 Environmental Education Activity Guide, p.327).

I created activities adapted from these three lessons. The lesson plans developed for the Forest Field Trips conducted for this study can be found in Appendix D. 


\section{Subjects}

The subjects for this study included 129 students in $3^{\text {rd }}-5^{\text {th }}$ grade at a public school in Gogebic County, Michigan located in the Western Upper Peninsula. A total of 155 students were present for the field trips, but some of these students turned in an incomplete pre- or posttest. These tests were not included in the study. Also one group of $3^{\text {rd }}$ grade students worked with a partner to complete the pre-and posttest. This group arrived late and was going to have less than an hour for the activities, though I planned for them to have 1.5 hours. I had them work with a partner to expedite the test-taking process in order to provide more time for the activities. Also, with the $5^{\text {th }}$ grade group, 14 students worked with a partner because the teachers did not have enough pencils and clipboards for this large group. Table 1 shows the number of student participants and tests taken for each of the five field trips conducted.

\section{Table 1: Student Participants and Tests Taken}

\begin{tabular}{cccccc}
\hline Grade & $\begin{array}{c}\text { \# Students } \\
\text { present }\end{array}$ & $\begin{array}{c}\text { \# Tests } \\
\text { completed }\end{array}$ & $\begin{array}{c}\text { \# Students took } \\
\text { test individually }\end{array}$ & $\begin{array}{c}\text { \# Students took } \\
\text { test with partner }\end{array}$ & $\begin{array}{c}\text { \# Non- } \\
\text { participating } \\
\text { students }\end{array}$ \\
\hline $3-1$ & 34 & 28 & 28 & 0 & 6 \\
$3-2$ & 36 & 10 & 0 & 20 & 16 \\
$4-1$ & 23 & 20 & 20 & 0 & 3 \\
$4-2$ & 24 & 23 & 23 & 0 & 1 \\
$5-1$ & 38 & 24 & 10 & 28 & 0 \\
\hline Totals & 155 & 105 & 81 & 48 & 26
\end{tabular}


Along with the logistical information I provided the teachers regarding the Forest Field Trips, I included a statement explaining the research I planned to conduct. In compliance with the IRB process, I also provided the teacher with an informed consent form to send home with all students to obtain parental permission for them to participate in the study. This is included in Appendix E.

\section{Data Collection}

A one-page, three-part, written test was developed to assess the participants' environmental knowledge related to the lessons. This test was administered directly prior to and directly after the experience. There are certain challenges associated with having students take a non-graded pre- and posttest. One challenge was making sure that the test was long enough to allow for adequate data collection, but short enough that the students would continue to be motivated to complete the test and provide accurate answers. I also wanted to make sure to have the students answer the questions in a way that minimizes the potential for correct answers to be guesses. For this reason, I avoided multiple choice or true/false questions and instead used short answer questions and fill-in-the-blank.

The following paragraphs include a description of each question that was asked on the test, along with how it was graded. 


\section{Question 1}

Students were presented with a list of ten products. They were asked to circle any of the ten products that they thought came from trees, and for the products that they circled they were asked to list the part of the tree it came from. This question was worth 20-points. Students were given one point for each product that they circled, indicating that it came from a tree. They were given another point if they accurately named the part of the tree the product was derived from.

\section{Question 2}

Students were asked the following open-ended, short answer question: How do you tell the difference between a red pine and a white pine? This question was worth 2-points. When grading this question, students were given one point for explaining that one can tell the difference between red pine and white pine by looking at the needles. They were given another point if they explained that red pine has two needles per bundle and white pine has five needles per bundle.

\section{Question 3}

Students were asked to interpret the following diagram and identify the type of branching. This question was worth 1-point and students received a point if they described the branch as opposite branching. 
Figure 1: An Illustration Showing Opposite Branching

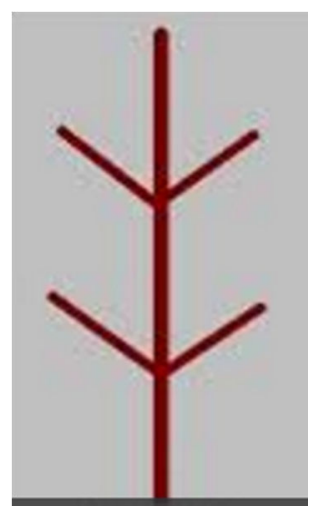

\section{Question 4}

Students were asked the following open-ended, short answer question: What is an increment borer? This question was worth 1-point. This question was worth 1-point and student received a point if they said an increment borer was a tool used to tell the age of a tree.

There were a total of 24-points on the test. In addition, on the posttest, a question was included asking students if they like participating in field trips like this and to write a sentence explaining their answer. The pre- and posttest, along with a grading rubric and samples of completed tests by students can be found in Appendix F.

\section{Data Analysis}

From this data, the mean pre- and posttest scores were determined for each group. The average gains were found for each of the four questions, as well as totals for each of the three grades that participated. The average normalized gain, which is used to evaluate the effectiveness of the learning tool (Hake, 1998), was also determined for each of the three grades. The data analysis procedures are discussed in more detail in Chapter 4 . 
In addition to the student assessments, the teachers were emailed a survey to complete on the implementation of the field trip. Questions were

also included to evaluate the factors involved in their decision to sign up for a Forest Field Trip. This Google Forms survey can be found in Appendix G.

During this study I served the dual role of environmental educatorteacher. After conducting each of the field trips I recorded detailed notes on various aspects of each particular group, such as the class dynamics, weather conditions, student interactions and anything else that could influence the results of this study or that I thought may be useful in the analysis of the data. These details are included in the following paragraphs summarizing each of the five groups.

\section{Summary of Each Group}

I conducted five field trips for a total of 157 students in Grades 3-5. As expected with research of this nature, certain variables were not able to be held constant, such as class size, number of adults present, day and time of the field trip and the dynamics within each group. The groups varied in size from 23-38 students, with one to four adults present, not including myself. The adults included teachers and parent volunteers and their main role was to keep the students on task.

Although I attempted to make each field trip experience as consistent as possible, unexpected factors also created additional variables with each group. All of these differences, along with how they may have affected the results, will be discussed in the following paragraphs. 
Grade: 3

Date: Friday, May 20

Participants: 34 students, 3 adults

The teacher warned me upon getting off of the bus that this was an active group and included many students with low attention spans. The bus also arrived late for this group, so at times I felt rushed to get through all of the activities I had planned. The mosquitos were bad at times, but that was to be expected this time of year, especially at this site. My overall impression of this group is that they were difficult to keep on task and though they were engaged in the activities they were easily distracted. The adults included one teacher and two parent volunteers.

\section{Grade: 3}

Date: Friday, May $20 \quad$ Time: 1:40-2:40pm Participants: 36 students, 4 adults

This group stayed more on-task than the first group. They also responded to prompts much quicker, though I still had to rush to get through all of the activities because of the shortened time. I was concerned about having enough time to complete all of the activities so I modified the preposttest taking by having the students work in groups of two. I figured that this would shorten the time it would take to administer the tests. Having the students work with a partner to complete the test would produce less data, but it would be of better quality. I considered giving the teacher the posttest to have the students take back in their classroom, but this would introduce variables that might have compromised the data. The adults that accompanied this group include two teachers and two parent volunteers. 
Grade: 4

\section{Group 4-1}

Date: Monday, May $23 \quad$ Time: 8:30-9:45am Participants: 23 students, 2 adults

The mosquitos were horrendous for this group. The students had a hard time concentrating and were complaining of getting bit by mosquitos. Despite this, the students responded well to prompts from myself and the teachers. I found out at the end of the field trip that the regular teacher was not present for this field trip, but the class was led by a substitute teacher and a student teacher. This information surprised me because the students were so well-behaved, which is not what I have experienced in the past when conducting field trips with substitute teachers present.

\section{Group 4-2}

\section{Grade: 4}

Date: Monday, May 23 Time: 10:15-11:25am Participants: 24 students, 1 adult

To avoid the mosquitos, I modified this field trip by conducting it in the schoolyard rather than at Lost Lake. We started the field trip in the classroom, with the students taking the pre-test at their desks. I also conducted the introduction indoors. When we completed the activities we went back to the classroom for the posttest. This class was very focused and engaged throughout the field trip. I didn't feel rushed at all during this field trip. Overall, I felt like this field trip was a success. 


\section{Group 5-1}

\section{Grade: 5}

\section{Date: Monday, May 23 Time: 12:45-2:05pm Participants: 38 students, 2 adults}

This group was both $5^{\text {th }}$ grade classes combined, with both teachers present. I was told that the students were well-behaved so the higher number of students would be manageable. I found this to be true. This field trip was conducted at Little Girl's Point, which is a park along the shore of Lake Superior, and located about 5-miles further from the school than Lost Lake. We chose this site because the slight breeze off of the lake would keep the mosquitoes away, and the students would be able to experience a field trip away from the school.

When the group arrived I realized that they only had 24 clipboards and pencils available for 38 students to I quickly thought of a way to randomly have some of the students work in pairs. I randomly passed out all of the clipboards and pencils that I had. I then asked the 14 students that did not get a clipboard or pencil to pair up with a student that did have one. This produced 14 groups and 10 individuals taking the tests.

My impression of this field trip was similar to that of the $4^{\text {th }}$ grade group that I conducted in the schoolyard. The students were engaged, ontask, and appeared to enjoy the activities. I felt that this may have been the best field trip out of the five I conducted. 
After conducting field trips with all five groups and taking into account the different experiences with each group I formed hypotheses regarding how well each group would perform on the posttests. My hypotheses include:

- The $5^{\text {th }}$ grade students would perform the highest on the posttest and have the highest knowledge gains. This is consistent to the hypothesis I formed prior to conducting the field trips, because of the assumed higher cognitive abilities of this group due to the students being older on average and therefore further along in their cognitive development. In addition, during the field trip the students were engaged and ontask, which led me to believe that the activities were effective in increasing their knowledge on the topics.

- The $4^{\text {th }}$ grade students that participated in the field trip at the school would be slightly lower, but very close to the $5^{\text {th }}$ grade scores and gains. These students are younger on average than the $5^{\text {th }}$ graders and therefore not as cognitively developed. After conducting the field trip in the schoolyard and having them take the pre- and posttest in the classroom I felt that the students may have had a slight advantage because they were less distracted when taking the test than the students who took it outdoors.

- The first $4^{\text {th }}$ grade group would have the lowest scores and gains. This group was very distracted by the mosquitos.

- The first $3^{\text {rd }}$ grade group would have the second lowest scores and gains. This group was very active and easily distracted. 


\section{Chapter 4: Results and Discussion}

The data was analyzed by finding the mean scores for the 24-point preand posttest. I further separated the data by each of the four questions to determine if there was variation in the scores between the questions. Means were analyzed by group and also by grade. I separated the $5^{\text {th }}$ grade group into those that took the test individually and those that took the test with a partner. The second $3^{\text {rd }}$ grade class also took the test with a partner. In addition to the means, the percentage gains for each question and the totals were calculated to determine the average normalized gains. A one-way analysis of variance (ANOVA) test was run on the mean scores of the pre-and posttest totals to determine if there was a statistical significant difference between the Grade 3, Grade 4, and Grade 5 mean scores. A one-tail t-test was run to evaluate the statistical significance of gains between the pre- and posttest scores.

\section{Means and Average Score Percentages}

When analyzing the results, the mean scores on all four questions and the total scores were found on the pre- and posttest, for all groups and for each grade. In addition, the gains were determined for each question and the totals for all groups and each grade. Table 2 shows the mean pre- and posttest scores and the gains for each of the questions and the totals. The standard deviations are included in parentheses for the total scores for each group and grade. 
Table 2: Pre- and Posttest Mean Scores

\begin{tabular}{|c|c|c|c|c|c|c|c|c|c|c|c|}
\hline \multirow[b]{2}{*}{ Group } & \multicolumn{2}{|c|}{$\begin{array}{c}\text { Question } 1 \\
\text { out of } 20\end{array}$} & \multicolumn{2}{|c|}{$\begin{array}{c}\text { Question } 2 \\
\text { out of } 2\end{array}$} & \multicolumn{2}{|c|}{$\begin{array}{c}\text { Question } 3 \\
\text { out of } 1\end{array}$} & \multicolumn{2}{|c|}{$\begin{array}{c}\text { Question } 4 \\
\text { out of } 1\end{array}$} & \multicolumn{3}{|c|}{$\begin{array}{c}\text { Total } \\
\text { out of } 24\end{array}$} \\
\hline & $\begin{array}{l}\text { Pre } \\
\text { Mean }\end{array}$ & $\begin{array}{l}\text { Post } \\
\text { Mean }\end{array}$ & $\begin{array}{l}\text { Pre } \\
\text { Mean }\end{array}$ & $\begin{array}{l}\text { Post } \\
\text { Mean }\end{array}$ & $\begin{array}{l}\text { Pre } \\
\text { Mean }\end{array}$ & $\begin{array}{l}\text { Post } \\
\text { Mean }\end{array}$ & $\begin{array}{l}\text { Pre } \\
\text { Mean }\end{array}$ & $\begin{array}{l}\text { Post } \\
\text { Mean }\end{array}$ & $\begin{array}{l}\text { Pre } \\
\text { Mean } \\
\text { (std) }\end{array}$ & Gains & $\begin{array}{c}\text { Post } \\
\text { Mean } \\
\text { (std) }\end{array}$ \\
\hline $\begin{array}{l}3-1 \\
(n=28)\end{array}$ & \multicolumn{2}{|c|}{$5.18 \quad 15.11$} & 0.00 & 1.00 & 0.00 & 0.18 & 0.00 & 0.68 & 5.21 & 11.07 & 16.29 \\
\hline 3-1 Gains & \multicolumn{2}{|c|}{9.93} & \multicolumn{2}{|c|}{1.00} & \multicolumn{2}{|c|}{0.18} & \multicolumn{2}{|c|}{0.68} & (2.09) & & (3.89) \\
\hline $\begin{array}{l}\text { 3-2 group } \\
(n=10)\end{array}$ & 5.90 & 13.90 & 0.00 & 0.70 & 0.00 & 0.30 & 0.00 & 0.10 & 5.90 & 9.00 & 14.90 \\
\hline 3-2 Gains & \multicolumn{2}{|c|}{8.00} & \multicolumn{2}{|c|}{0.70} & \multicolumn{2}{|c|}{0.30} & \multicolumn{2}{|c|}{0.10} & $(2.26)$ & & (3.70) \\
\hline $3^{\text {rd }}$ total & 5.37 & 14.79 & 0.00 & 0.92 & 0.00 & 0.21 & 0.00 & 0.53 & 5.39 & 10.53 & 15.92 \\
\hline $3^{\text {rd }}$ Gains & \multicolumn{2}{|c|}{9.42} & \multicolumn{2}{|c|}{0.92} & \multicolumn{2}{|c|}{0.21} & \multicolumn{2}{|c|}{0.53} & $(2.16)$ & & (3.89) \\
\hline $\begin{array}{l}4-1 \\
(n=20)\end{array}$ & 6.10 & 15.75 & 0.05 & 0.95 & 0.10 & 0.40 & 0.00 & 0.35 & 6.25 & 10.85 & 17.10 \\
\hline 4-1 Gains & \multicolumn{2}{|c|}{9.65} & \multicolumn{2}{|c|}{0.90} & \multicolumn{2}{|c|}{0.30} & \multicolumn{2}{|c|}{0.35} & $(2.77)$ & & (4.33) \\
\hline $\begin{array}{l}4-2 \\
(n=23)\end{array}$ & 6.09 & 17.00 & 0.13 & 1.30 & 0.00 & 0.39 & 0.00 & 0.57 & 6.22 & 12.48 & 18.70 \\
\hline 4-2 Gains & \multicolumn{2}{|c|}{10.91} & \multicolumn{2}{|c|}{1.17} & \multicolumn{2}{|c|}{0.39} & \multicolumn{2}{|c|}{0.57} & $(2.34)$ & & (2.05) \\
\hline $4^{\text {th }}$ total & 6.09 & 16.42 & 0.09 & 1.14 & 0.05 & 0.40 & 0.00 & 0.47 & 6.23 & 11.72 & 17.95 \\
\hline $4^{\text {th }}$ Gains & \multicolumn{2}{|c|}{10.33} & \multicolumn{2}{|c|}{1.05} & \multicolumn{2}{|c|}{0.35} & \multicolumn{2}{|c|}{0.47} & $(2.55)$ & & (3.41) \\
\hline $\begin{array}{l}5-1 \\
(n=10)\end{array}$ & 5.50 & 16.40 & 0.10 & 0.90 & 0.00 & 0.10 & 0.00 & 0.60 & 5.60 & 11.80 & 17.40 \\
\hline 5-1 Gains & \multicolumn{2}{|c|}{10.90} & \multicolumn{2}{|c|}{0.80} & 0 . & & & & (2.33) & & (3.17) \\
\hline $\begin{array}{l}5-1 \text { group } \\
(n=14)\end{array}$ & 7.21 & 18.86 & 0.14 & 1.29 & 0.00 & 0.57 & 0.00 & 0.86 & 7.36 & 13.36 & 20.71 \\
\hline 5-1g Gains & & 64 & & & 0. & & & & (2.19) & & (1.79) \\
\hline $5^{\text {th }}$ total & 6.50 & 17.83 & 0.13 & 1.13 & 0.00 & 0.38 & 0.00 & 0.75 & 6.63 & 12.71 & 19.33 \\
\hline $5^{\text {th }}$ Gains & & & & & 0. & & & & (2.41) & & (2.95) \\
\hline
\end{tabular}

When looking at the total pre- and posttest scores for the combined grades, Grade 3 had the lowest means and gains, $4^{\text {th }}$ grade had the next lowest and Grade 5 had the highest. The $5^{\text {th }}$ grade students that worked in a group scored much higher on all parts of the test and also had higher gains than the students that worked individually. 
One reason for this may be because working in a group allows for collaboration between students, which may produce higher scores. Another possibility is that when I asked the 14 students without the test-taking materials to pair up with one of the 24 students that did have the materials, they might have chosen the higher performing students as partners. This would leave the 10 students working individually to be on average, lower performing students. The $3^{\text {rd }}$ grade groups had one class (3-1) that took the tests individually and another that took the test with a partner (3-2). These scores and gains do not support the hypothesis that the collaboration that comes with working in groups produces higher scores. The 3-2 group had higher mean scores on the pretest for Question 1 and the total score, but the 3-1 group had higher posttest scores and gains with the majority of the tests and questions. I attribute this in part to the bus coming earlier than expected to pick up the students, resulting in many of them rushing to complete the test. This also explains why 18 tests were not included in the results. The students failed to complete over half of the posttest, therefore the data was compromised.

After conducting the field trip with the $4^{\text {th }}$ grade group (4-1) that was distracted by mosquitos, I assumed that they were going to have many incomplete tests and therefore data that would not be usable for this study. When glancing through the tests I was surprised at the number of completed tests. Before grading the tests, I assumed that this group would have very low scores and gains because of the mosquitos. 
Table 2 shows that the means scores and gains were lower than the other $4^{\text {th }}$ grade group, but higher than the $3^{\text {rd }}$ grade groups. This is consistent with my hypothesis that there would be a difference in the mean scores and gains between the grades, due to cognitive development (Powell and Kalina, 2009). One possible explanation for the higher posttest means for Group 4-2 was the difference in location. The $4^{\text {th }}$ grade field trip took place at the school to avoid the abundant mosquitos at Lost Lake. The field trip began and ended in the classroom. This is potentially a very effective strategy for conducting an outdoor field trip. Having an opportunity to introduce the field trip, provide an overview and any other pertinent information while the students are in the classroom, may avoid distraction due to novelty (Randler, Ilg \& Kern, 2005).

In Jean Piaget's book, The Child's Conception of the World, he explains that within this concrete operational stage, (on average, 7-11 year olds) which almost all of these $3^{\text {rd }} 5^{\text {th }}$ grade students would be classified into, students have vastly different understandings of where wood comes from. It is during this concrete operational stage that students will begin to understand that wood comes from trees (Piaget, 1927). This may no longer be accurate for students today, but to some degree there may be similarities.

Table 3: Pretest Average Score Percentage for Each Grade

\begin{tabular}{clllll}
\hline Grade & $\begin{array}{c}\text { Question 1 } \\
\text { out of 20 }\end{array}$ & $\begin{array}{l}\text { Question 2 } \\
\text { out of 2 }\end{array}$ & $\begin{array}{l}\text { Question 3 } \\
\text { out of 1 }\end{array}$ & $\begin{array}{l}\text { Question 4 } \\
\text { out of 1 }\end{array}$ & $\begin{array}{c}\text { Total } \\
\text { out of 24 }\end{array}$ \\
\hline 3 & $26.84 \%$ & $0.00 \%$ & $0.00 \%$ & $0.00 \%$ & $22.48 \%$ \\
4 & $30.47 \%$ & $4.65 \%$ & $4.65 \%$ & $0.00 \%$ & $25.97 \%$ \\
5 & $32.50 \%$ & $6.25 \%$ & $0.00 \%$ & $0.00 \%$ & $27.60 \%$ \\
\hline
\end{tabular}


The average score percentages, or the percentage of correct answers, for each question, and the totals on the pretest, for each grade level are shown in Table 3. Students in all of the grades scored very low on the open-ended question. I intentionally asked open-ended questions that I did not think many students would have the prior knowledge to answer correctly so that the posttest score would be an accurate representation of knowledge gained.

Only two $4^{\text {th }}$ grade students, out of all students tested in grades $3^{\text {rd }}-5^{\text {th }}$, earned a point on the pretest for Question 3, which asked students to interpret an illustration and determine the type of branching. The correct answer was opposite branching, as opposed to alternate branching. Two students answered "maple tree", which is a tree species with opposite branching, therefore a point was given for this answer. It is unknown whether this answer was a guess on behalf of the students, or if they knew this information prior to the activity. The grading strategy is explained in more detail in Chapter 3, and the grading rubric is included in Appendix F. Table 3 shows that the average score percentage increased by grade with both Question 1 and the total pretest score.

Table 4: Posttest Average Score Percentage for Each Grade

\begin{tabular}{clllll}
\hline Grade & $\begin{array}{l}\text { Question 1 } \\
\text { out of 20 }\end{array}$ & $\begin{array}{l}\text { Question 2 } \\
\text { out of 2 }\end{array}$ & $\begin{array}{l}\text { Question 3 } \\
\text { out of 1 }\end{array}$ & $\begin{array}{l}\text { Question 4 } \\
\text { out of 1 }\end{array}$ & $\begin{array}{c}\text { Total } \\
\text { out of 24 }\end{array}$ \\
\hline 3 & $73.95 \%$ & $30.70 \%$ & $21.05 \%$ & $52.63 \%$ & $66.34 \%$ \\
4 & $82.09 \%$ & $37.98 \%$ & $39.53 \%$ & $46.51 \%$ & $74.81 \%$ \\
5 & $89.17 \%$ & $37.50 \%$ & $37.50 \%$ & $75.00 \%$ & $80.56 \%$ \\
\hline
\end{tabular}


Similar to the pretest score percentages, the posttest average score percentage increased by grade with Question 1 and the total posttest scores. These categories also had the highest percentage scores, with the exception of the $5^{\text {th }}$ grade score of 75 percent for Question 4 . The $4^{\text {th }}$ grade students scored slightly lower than the $3^{\text {rd }}$ grade students on this question, which asked about increment borers.

There are two possible explanations for the lower $4^{\text {th }}$ grade scores. First, I conducted this activity last, and with the $4^{\text {th }}$ grade group that was dealing with the mosquitos they may have been too distracted at this point to focus on the name of the tool that we were using. Also, I conducted the other group's field trip in the schoolyard, and because there were a limited number of trees I only used the increment borer on one tree, as opposed to doing it a few times with other groups. Putting less emphasis on this activity may be another factor that affected the posttest score. In addition, because I had more time with the $5^{\text {th }}$ grade group and there were plenty of trees available, we spent more time coring trees with the increment borer than with the other groups. This factor may be why the $5^{\text {th }}$ grade scored so high on Question 4 .

\section{Table 5: Average Gain Percentages for Each Grade}

\begin{tabular}{llllll}
\hline Grade & $\begin{array}{l}\text { Question 1 } \\
\text { out of 20 }\end{array}$ & $\begin{array}{l}\text { Question 2 } \\
\text { out of 2 }\end{array}$ & $\begin{array}{l}\text { Question 3 } \\
\text { out of 1 }\end{array}$ & $\begin{array}{l}\text { Question 4 } \\
\text { out of 1 }\end{array}$ & $\begin{array}{c}\text { Total } \\
\text { out of 24 }\end{array}$ \\
\hline 3 & $47.11 \%$ & $46.05 \%$ & $21.05 \%$ & $52.63 \%$ & $43.86 \%$ \\
4 & $51.63 \%$ & $52.33 \%$ & $34.88 \%$ & $46.51 \%$ & $48.84 \%$ \\
5 & $56.67 \%$ & $50.00 \%$ & $37.50 \%$ & $75.00 \%$ & $52.95 \%$ \\
\hline
\end{tabular}


Table 5 shows the average gain percentages for each grade. The results show that for Questions 1 and Question 3, and for the total, the gains increased as the grade increased. This supports my hypothesis that on average, the higher the grade the student is in, the more knowledge that will be gained after participating in this Forest Field Trip.

Question 3 had the lowest gains for all three grades. This question asked the students to interpret the illustration shown in Figure 1 in Chapter 3. This illustration can also be viewed in Appendix F. It is possible that this question was too advanced for the majority of students' cognitive abilities. Another possibility is that the teaching of this concept was not as effective as the other strategies. As explained in the lesson plan in Appendix D, to show the difference between opposite and alternate branching trees I showed students a sample of both and then showed them trees with each type of branching. The activity may have been more effective in producing knowledge gains if I would have taken it a step further and had the students either sort branches into the two categories, or find a tree with each type of branching.

\section{Normalized Gains}

The normalized gain is a test of practical significance of the gains. It measures the instructional effect of conceptual knowledge. The normalized gain, as determined by Hake (1998), is the average increase in students' scores divided by the maximum possible gain (Hungwe, et. al. 2007). 
The following equation was used to determine the average gains for each grade and each type of question:

Figure 2: Average Normalized Gain Equation

$$
\begin{aligned}
& <g>=\frac{\text { average gain }(\%)}{\text { maximum possible gain }(\%)} \\
& =\frac{(\text { posttest average score }(\%)-\text { pretest average score }(\%))}{100-\text { pretest average score }(\%)}
\end{aligned}
$$

It is considered that:

$\mathrm{g}>0.70$ is a high gain

$0.30<\mathrm{g}<0.70$ is a medium gain

$\mathrm{g}<0.30$ is a low gain

\section{Table 6: Average Normalized Gain for Each Grade}

\begin{tabular}{cccccc}
\hline Grade & Question 1 & Question 2 & Question 3 & Question 4 & Total \\
\hline 3 & $0.47 \%$ & $0.46 \%$ & $0.21 \%$ & $0.53 \%$ & $0.44 \%$ \\
4 & $0.52 \%$ & $0.52 \%$ & $0.35 \%$ & $0.47 \%$ & $0.49 \%$ \\
5 & $0.57 \%$ & $0.50 \%$ & $0.38 \%$ & $0.75 \%$ & $0.53 \%$ \\
\hline
\end{tabular}

All of the normalized gains were in the medium category of .30-.70, except for Question 3 for the $3^{\text {rd }}$ grade, which was considered a low gain and Question 4 for the $5^{\text {th }}$ grade, which was considered a high gain. These results show that conceptual understanding did occur as a result of the field trips. The gains were marginally higher as the grades went up.

Mean scores on the 24-point test increased significantly from the pretest to the posttest, with the $3^{\text {rd }}$ grade ( 10.53 points \pm 4.23 points, $n=43$ ), the $4^{\text {th }}$ grade (11.72 points \pm 4.11 points, $\left.n=38\right)$ and the $5^{\text {th }}$ grade $(12.71$ points \pm 3.03 points, $\mathrm{n}=24$ ) (paired t-test, $\mathrm{p}<.0001$ ). 


\section{Analysis of Variance}

An analysis of variance was applied on the pre-and posttest scores. The goal was to assess if there was a statistically significant difference between the grades both before and after the field trip experience. The results are summarized in Table 7 and 8 .

Table 7: Single-Factor ANOVA Test for Pretest Scores

\begin{tabular}{ccccc}
\multicolumn{5}{l}{ SUMMARY } \\
\hline Groups & Count & Sum & Average & Variance \\
\hline 3rd & 38 & 205 & 5.395 & 4.786 \\
4th & 43 & 268 & 6.233 & 6.659 \\
5th & 24 & 159 & 6.625 & 6.071 \\
\hline
\end{tabular}

\begin{tabular}{lcccccc} 
ANOVA & \multicolumn{1}{c}{ Source of } & & & & & \\
$\quad$ Variation & SS & $d f$ & MS & F & P-value & Fcrit \\
\hline Between Groups & 25.584 & 2 & 12.792 & 2.188 & 0.117 & 3.085 \\
Within Groups & 596.378 & 102 & 5.847 & & & \\
& & & & & & \\
Total & 621.962 & 104 & & & & \\
\hline
\end{tabular}

There was no significant difference on the pretest mean scores between each grade $\left(F_{2,102}=2.188, p>.05\right)$. Table 8 shows the analysis of variance results of the posttest total scores for each grade. There is a significant difference in the mean scores on the posttest mean scores between each grade $\left(F_{2,102}=7.314, p<.005\right)$. 
Table 8: Single-Factor ANOVA test for Posttest Scores

\begin{tabular}{ccccc}
\multicolumn{6}{l}{ SUMMARY } \\
\hline Groups & Count & Sum & Average & Variance \\
\hline 3rd & 38 & 605 & 15.921 & 15.534 \\
4th & 43 & 772 & 17.953 & 11.903 \\
5th & 24 & 464 & 19.333 & 9.101 \\
\hline
\end{tabular}

\begin{tabular}{|c|c|c|c|c|c|c|}
\hline $\begin{array}{l}\text { Source of } \\
\text { Variation }\end{array}$ & SS & $d f$ & MS & $F$ & $P$-value & F crit \\
\hline Between Groups & 184.130 & 2 & 92.065 & 7.314 & 0.0011 & 3.085 \\
\hline Within Groups & 1284.003 & 102 & 12.588 & & & \\
\hline Total & 1468.133 & 104 & & & & \\
\hline
\end{tabular}

The summary for each of the ANOVA tests shows that the average scores increased on both the pre- and posttest as the grade level increased. The variance decreased from $3^{\text {rd }}$ to $5^{\text {th }}$ grade on the posttest. On the pretest, $3^{\text {rd }}$ grade had the lowest variance and $4^{\text {th }}$ grade had the highest variance. This shows that there was a larger range of mean scores in the $4^{\text {th }}$ grade groups. This may be partially attributed to the difference in the field trips with the two $4^{\text {th }}$ grade groups. One was at Lost Lake and the mosquitos negatively affected the students' ability to concentrate. The other field trip took place in the schoolyard, with the test-taking occurring in the classroom.

The posttest included a question asking students if they would like to participate in more outdoor activities and to explain why or why not. Many students did not answer this question. 
There were only five students that answered "No" to this question. Four of the students explained that they did not like the bugs and one student said that there was not enough time. Even with the number of mosquitos present with the 4-1 group, there were still fourteen students that answered "Yes" to this question. Some of the explanations for why students would like to participate in more of these outdoor learning experiences include:

- I love learning outside

- It is fun

- Because we get to be outside!

- I love nature

- Because it's good for us to get outside

- I learned a lot of things I never knew and it was really fun

- You learn a lot while having fun

- I think this was very educational

- I like getting out of school

- It gets us out of school and teaches us about nature

- It allowed us to go outside while learning valuable knowledge

- Because it was awesome

- I like learning about trees

- I would like to learn more

- Because it's science

- To learn more about nature and where products come from 


\section{Teacher Evaluations}

The teachers that participated in the Forest Field Trips were sent evaluations via a Google Form. Two teachers from Houghton County and one teacher from Gogebic County completed the evaluation. In addition to these responses are five responses from teachers in Marquette County who participated in a similar outdoor experience I offered, which was not a part of this study. Along with questions pertaining to the field trip experience, teachers were asked if they would be more likely to take their students on a field trip if the transportation costs were reimbursed. All of the teachers responded that they would.

In addition to the Yes/No responses, the following comments were included:

- Our school has a tight budget

- I hate asking parents for (more) money to take their children on a field trip

- Tight budgets prohibit extras. I feel bad even asking.

Teachers were also asked the following question: "Are you more likely to take your students on a field trip if a natural resource professional is present to lead the activities?" All of the teachers responded 'yes' to this question as well. 
In addition to the yes/no responses, the following comments were noted:

- Good for all involved. Kids and teachers appreciate it!

- Expertise, especially from a work professional independent from the school, is impactful for the students and offers perspective from beyond the classroom experience.

- With a science background I am comfortable explaining many things to students, but an expert in the given field is always nice for students to see and interact with.

The results from this survey align with research that shows teachers prefer having an environmental professional available to lead the activities (Meichtry \& Harrell, 2002) when participating in outdoor field trips. Also, funding is one of the main barriers to participation in outdoor field trips (Behrendt \& Franklin 2014, Meichtry \& Harrell 2002, Michie 1998, Yunker 2011). 


\section{Chapter 5: Conclusion}

This research aimed to assess a forest field trip experience and determine the impacts it had on students' environmental knowledge. The findings of the three research questions posed at the beginning of the study are summarized below.

\section{What strategies have been used to conduct forest-based environmental education programs in the Western Upper} Peninsula?

The Western UP Center has conducted the Outdoor Science Investigations Program since 2001 (WUP Center 2016). There have been numerous strategies implemented by the Center that have contributed to the success of this program. Other research conducted in the area of environmental education has indicated the importance of developing a program with activities that directly align to curriculum standards (Yunker 2011). All of the Outdoor Science Investigations align to the Michigan Science Grade Level Content Expectations. Also, giving the program the title "Outdoor Science Investigations" rather than "Forest Field Trips" portrays more clearly a program that aligns to curriculum standards and involves a valuable learning experience that teachers can justify having their students participate in.

The results of my research and that of Meichtry \& Harrell (2002), show that teachers value having a natural resource professional available to lead the outdoor programming. While serving as the Outdoor Field Trip Coordinator at the Western UP Center, I had to at times recruit other presenters because I was unable to fulfill all of the requests on my own. 
According to the teachers that responded to the survey I conducted for this study, some teachers prefer having a natural resource professional leading the field trip because they do not feel comfortable with their ability to teach the content. Other teachers are confident in their abilities to teach the content, or take their students outdoors, but they feel that having their students learn from someone other than them is a valuable experience.

The cost associated with transportation for field trips is one of the major challenges associated with participation (Behrendt \& Franklin 2014, Meichtry \& Harrell 2002, Michie 1998, Yunker 2011). Program such as the Woods to Wheels! Transportation fund make forest field trips more feasible for many schools operating on tight budgets.

The Western UP Center and Copper Country Intermediate School District have hosted numerous teacher workshops that educate teachers on environmental education curriculum, such as Project Learning Tree and Project WET, as well as effective strategies for outdoor learning. These experiences were what teachers expressed as one of their main needs in increasing their teaching of environmental education to their students (Meichtry \& Harrell, 2002).

What has been the impact of the strategies on students' environmental knowledge?

As shown in many other studies (Ghent, Parmer, \& Haines 2013, Powell \& Wells 2002, Bogner 1998), statistically significant knowledge gains were supported by my study. 
Knowledge was gained with all of the groups, even with the groups that experienced less than ideal conditions such as mosquitos, large groups, a shortened timespan and a modified location.

Mean scores increased significantly from the pretest to the posttest in the $3^{\text {rd }}, 4^{\text {th }}$ and $5^{\text {th }}$ grades. The activities conducted for this study produced primarily medium gains according to the average normalized gain equation developed by Hake (1998). All of the results of my study show the highest gains occurred with the $5^{\text {th }}$ grade students, followed by the $4^{\text {th }}$ grade. The $3^{\text {rd }}$ grade students had the lowest average knowledge gains.

\section{In what ways if any, can the conduct of the learning} experiences be improved?

Current opportunities such as teacher workshops or transportation reimbursements should continue to be advertised and promoted. Research conducted by Behrendt \& Franklin (2014) emphasized the importance of giving students freedom for exploration and discovery within clear boundaries. This style of learning is different than the typical classroom setting, where the students are sitting at their desks listening to the teacher. When outdoor learning occurs on a regular basis, even if it just in the schoolyard, it decreases novelty, therefore increasing the effectiveness (Randler, Ilg \& Kern, 2005).

The results of my study show the lowest knowledge gains with the $3^{\text {rd }}$ grade students. If the activities were modified slightly, the younger students might have scored higher on the posttest. Repeating concepts, or showing more visuals are some possible strategies. 


\section{Study Limitations}

There are numerous variables involved with educational research that are difficult to avoid. Prior to conducting the field trips I knew that the number of students in each group would vary, along with the number of adults present. Despite conducting the same activities for each group, each experience ended up being slightly different.

Certain variables arose while conducting the field trips, which should be expected with outdoor programming of this nature. The amount of time each group attended the field trip ended up being less than the 1.5-hours I planned for because of the transportation logistics. The heavy mosquitos were a distraction for one group and resulted in a location change for two other groups. I also planned on having all of the students complete the pre- and posttests individually, but some students ended up taking the test with a partner. I considered these variables when analyzing the data and used these differences as an opportunity for comparison.

Prior to developing this study, I searched for an assessment tool that could be used to measure the knowledge gained for a particular environmental education curriculum. I could not locate an adequate assessment tool, therefore I created my own. I experienced challenges when developing the assessment. For example, I wanted the test long enough to collect adequate data, but not too long that the students wouldn't complete the test. Also, I chose to ask open-ended questions that would be hard for a student to guess the correct answer, but these open-ended, short answer questions also produced low scores on both the pre- and posttests. 


\section{Further Research}

There are many opportunities to expand upon the research that I conducted with the Gogebic County, $3^{\text {rd }}-5^{\text {th }}$ grade students. Replicating this same study with another group of students would allow for a comparison to the results found in this paper. Delaying the administration of the posttest to a week, or a month after the field trip would allow for analysis of how much knowledge is retained (Bogner, 1998).

Many researchers interested in assessing the knowledge gained through environmental experiences are forced to create their own assessment tool because of the lack of existing reliable instrumentation (Carrier, 2009). According to Millar (2013), these assessment tools are rarely validated by peer review to the extent that they should be and therefore produce weak outcome measures that limit the impact of the research. If an environmental education curriculum such as Project Learning Tree had a reliable assessment tool that could be used to evaluate knowledge gains, even for a few of the lessons, this would open up numerous opportunities for future research. 


\section{References}

Adkins, C. \& Simmons, B. (2002). Outdoor, experiential, and environmental education: Converging or diverging approaches? ERIC Digest.

American Forest Foundation. (2007). Pre K-8 Environmental Education Activity Guide. Project Learning Tree.

American Forest Foundation. 2016. Project Learning Tree. www.plt.org

American Tree Farm System. (2016). Wheels to Woods Application. www.treefarmsystem.org/school-forests.

Behrendt, M. and Franklin, T. (2014). A review of research on outdoor field trips and their value in education. International Journal of Environmental \& Science Education. 9, 235-245.

Bierle, S. and Singletary, T. J. (2008). Environmental Education and Related Fields in Idaho Secondary Schools. The Journal of Environmental Education. 39:3, 19-31.

Bogner, F. (1998). The Influence of Short-Term Outdoor Ecology Education on Long-Term Variables of Environmental Perspective. The Journal of Environmental Education. 29:4.

Broda, H. W. (2007). Schoolyard Enhanced Learning: Using the Outdoors as an Instructional Tool, $K-8$. Stenhouse Publishers.

Carrier, S. J. (2009). Environmental education in the schoolyard: Learning styles and gender. The Journal of Environmental Education. 40:3, 2-12.

Faber T. A. and Kuo, F. E. (2009). Children with attention deficits concentrate better after a walk in the park. Journal of Attention Disorders. 12:5, 402-409.

Ghent, C., Parmer, G. and Haines, S. (2013). An Evaluation of "Forests of the World", a Project Learning Tree Secondary Module. Research in Higher Education Journal. Volume 19.

Gruenewald, D. A. and Manteaw, B.O. (2007). Oil and Water Still: How No Child Left Behind limits and distorts environmental education in US schools. Environmental Education Research. 13:2. 171-188.

Hake, R. (1998). Interactive Engagement Versus Traditional Methods: A SixThousand Student Survey of Mechanics Test Data for Inroductory Physics Courses. American Journal of Physics. 66, 64-67. 
Haywood, B. K. (2014), A "Sense of Place" in Public Participation in Scientific Research. Science Education. 98: 64-83.

Hungwe, K. N., Sorby, S., Drummer, T., and Molzon, R. (2007). Preparing K12 Students for Engineering Studies by Improving 3-D Spatial Skills. The International Journal of Learning. 14:2, 127-135.

Kyung-Ok, K. (2003). An inventory for assessing environmental education curricula. The Journal of Environmental Education. 34:2, 12.

Leeming, F.C., Porter, B.E., Dwyer, W.O., Bracken, B.A. (1995). Children's Environmental Attitude and Knowledge Scale: Construction and validation. The Journal of Environmental Education. 26:3, 22-31.

Meichtry, Y. and Harrell, L. (2002). An environmental education needs assessment of K-12 teachers in Kentucky. The Journal of Environmental Education. 33:3, 21.

Michie, M. (1998). Factors influencing secondary science teachers to organize and conduct field trips. Australian Science Teacher's Journal. 44, 43-50.

Millar, R. (2013). Valuing Assessment in Science Education: Pedagogy, Curriculum, and Policy. Springer Science and Business Media. 55

No Child Left Inside Coalition. Powered by the Chesapeake Bay Foundation. www.cbf.org/ncli

Orion, N., Hofstein, A., Tamir, P. and Giddings, G. J. (1997). Development and validation of an instrument for assessing the learning environment of outdoor science activities. Science Education. 81: 161-171.

Piaget, Jean. (1927). The Child's Conception of the World. London: Routledge Kegan Paul LTD. 333-337.

Powell, K.C. and Kalina, C. (2009). Cognitive and social constructivism: developing tools for an effective classroom. Education. 130:2.

Powell, K. and Wells, M. (2002). The effectiveness of three experiential teaching approaches on student science learning in fifth-grade public school classrooms. The Journal of Environmental Education. 33:2, 33.

Powers, A. L. (2004). An evaluation of four place-based education programs. The Journal of Environmental Education, 35:4, 17-32.

Project Wet Foundation. 2011. Project WET Curriculum and Activity Guide 2.0. 
Randler, C., Ilg, A., and Kern, J. (2005). Cognitive and emotional evaluation of an amphibian conservation program for elementary school students. The Journal of Environmental Education. 37:1, 43-52.

Walsh-Daneshmandi, A. and MacLachlan, M. (2006). Toward effective evaluation of environmental education: Validity of the children's environmental attitudes and knowledge scale using data from a sample of Irish adolescents. The Journal of Environmental Education. 37:2, 13-23.

Wells, N.M. and Lekies, K.S. (2006). Nature and the Life Course: Pathways from Childhood Nature Experiences to Adult Environmentalism. Children, Youth and Environments. 16:1.

Western Upper Peninsula Center for Science, Mathematics and Environmental Education. 2015. www.wupcenter.mtu.edu/education/fieldtrips

Yunker, M. L. (2011). A systemic examination of the introduction of an outdoor learning-based science curriculum to students, their teacher, and the school principal. Available from PsycINFO. 
Appendix A: Outdoor Science Investigations brochure
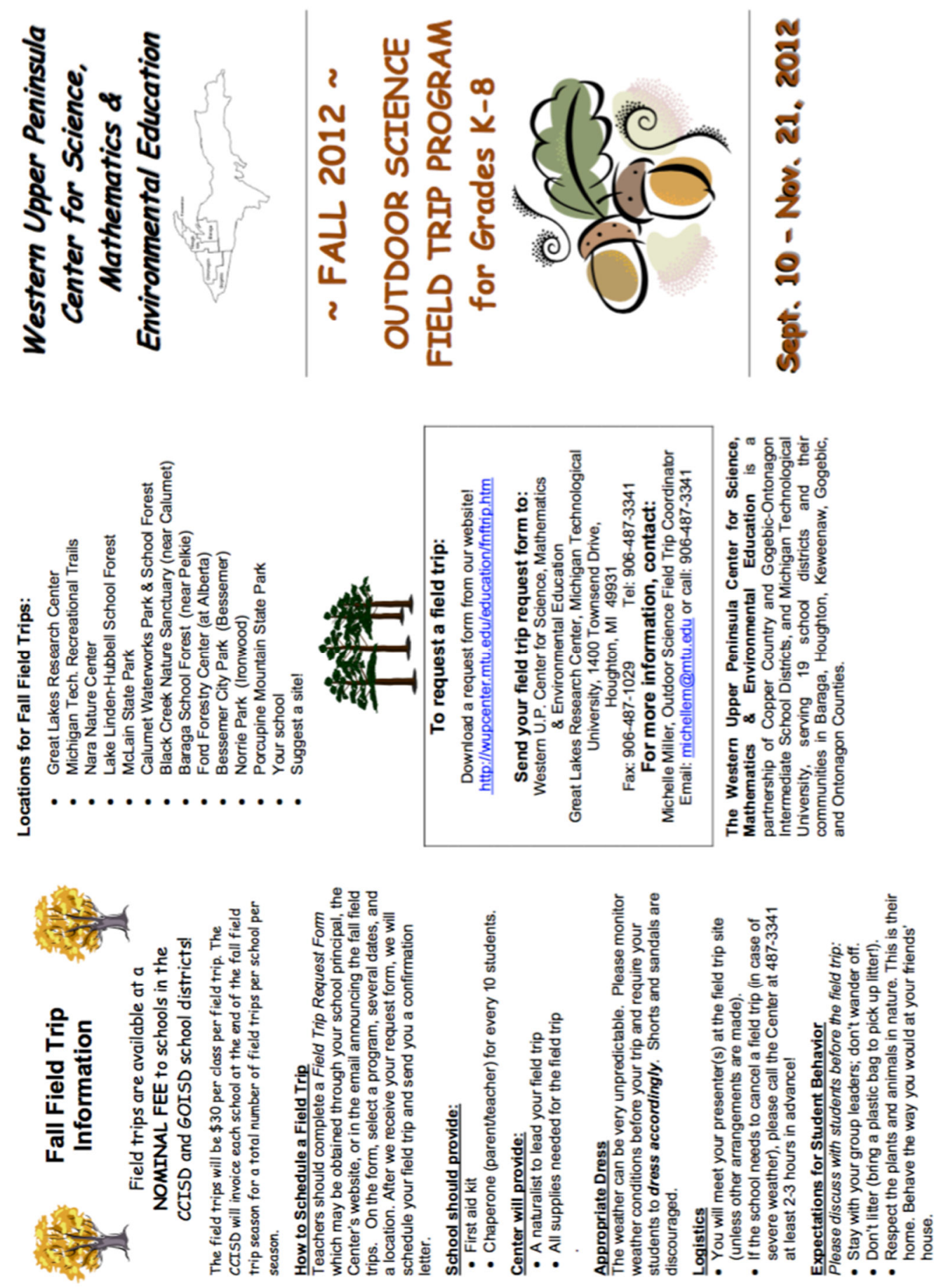

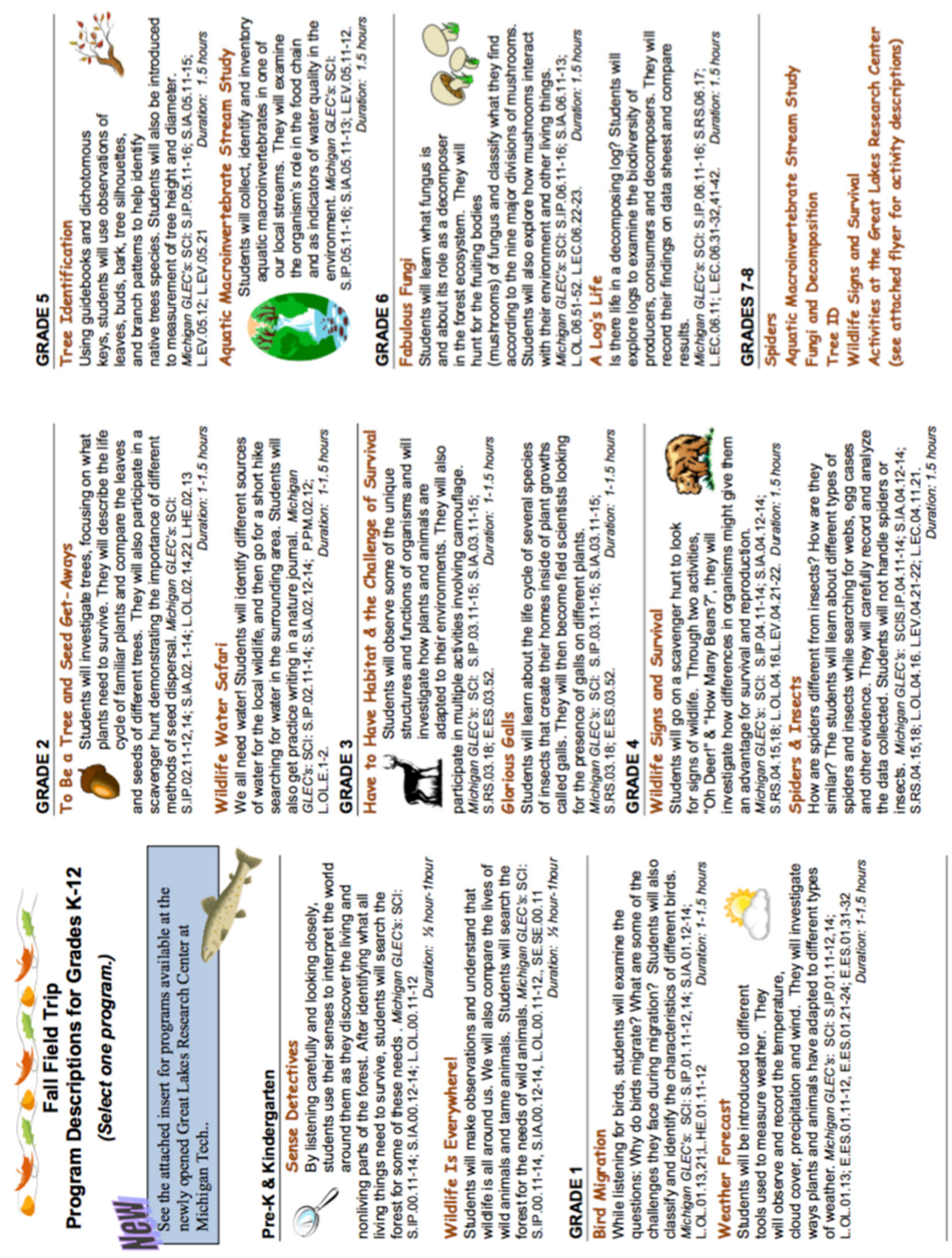


\section{Appendix B: Michigan Science Grade Level Content Expections}

Grade Standard

3

S.IP.03.11 Make purposeful observation of the natural world using the appropriate senses.

S.IP.03.12 Generate questions based on observations.

$\begin{array}{lll}x & x & x\end{array}$

$x \quad x \quad x$

S.IA.03.12 Share ideas about science through purposeful conversation in collaborative groups.

S.IA.03.13 Communicate and present findings of observations and investigations.

S.RS.03.14 Use data/samples as evidence to separate fact from opinion.

S.RS.03.15 Use evidence when communicating scientific ideas.

L.OL.03.41 Classify plants on the basis of observable physical characteristics (roots, leaves, stems, and flowers).

L.EV.03.11 Relate characteristics and functions of observable parts in a variety of plants that allow them to live in their environment (leaf shape, thorns, odor, color).

$x$

E.ES.03.51 Describe ways humans are dependent on the natural environment (forests, water, clean air, Earth materials) and constructed environments (homes, neighborhoods, shopping malls, factories, and industry).

E.ES.03.52 Describe helpful or harmful effects of humans on the environment (garbage, habitat destruction, land management, renewable, and non-renewable resources).

E.SE.03.31 Identify Earth materials used to construct some common objects (bricks, buildings, roads, glass).

$\mathrm{X}$ 
S.IP.04.11 Make purposeful observation of the natural world using the appropriate senses

$\mathrm{X}$

$\mathrm{X}$

S.IP.04.12 Generate questions based on observations.

S.IA.04.12 Share ideas about science through purposeful conversation in collaborative groups.

$\mathrm{X}$

S.IA.04.13 Communicate and present findings of observations and investigations.

S.RS.04.14 Use data/samples as evidence to separate fact from opinion.

S.RS.04.18 Describe the effect humans and other organisms have on the balance of the natural world.

$x$

L.OL.04.15 Determine that plants require air, water, light, and a source of energy and building material for growth and repair.

$\mathbf{X}$

\section{Grade Standard}

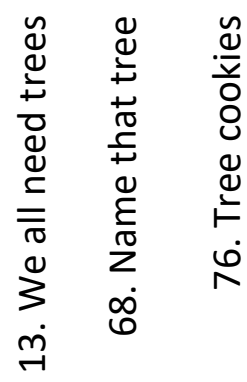

\section{5}

S.IP.05.11 Generate scientific questions based on observations, investigations, and research.

$\mathrm{X} \quad \mathrm{X}$

S.IA.05.13 Communicate and defend findings of observations and investigations using evidence.

$\mathbf{X}$

S.RS.05.17 Describe the effect humans and other organisms have on the balance in the natural world. 


\section{Appendix C: Wheels to Woods! Application}

\section{Wheels to Woods! - a School to Forest Bus Fund}

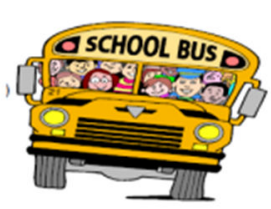

Purpose: The purpose of the Wheels to Woods! Fund is to provide funding to K-12 schools to pay for transportation costs for an educational field trip to a nearby forest. This grant is not competitive - funds will be awarded if available and if the field trip provides outdoor education in a forest for $\mathrm{K}-12$ students.

Eligibility: Any public or private K-12 school is eligible to apply for funds to go on a field trip to a forest owned by the school, or to a private forest (Tree Farm, family, organization), or to a public forest (federal, state, local). Other groups for young people like Girl Scouts, Boy Scouts, 4-H, FFA, and church groups are eligible to apply, but are a secondary priority to school groups. Any forest, regardless of ownership, is eligible to host the field trip.

Award: The Wheels to Woods! Fund will reimburse actual transportation costs up to $\$ 350$ per bus with a maximum award of $\$ 1,000$ per school or group per academic year. Notification of the award will occur within 15 days of receiving the Application (page 3). The payment will be made to the school after the field trip occurs and the school provides a brief Report (page 4) and an invoice to document actual costs.

Forest Connections: If a school does not own forest land, the Michigan Tree Farm Committee can connect a school with a nearby private landowner who enjoys hosting field trips to their family forest that is certified by the American Tree Farm System. If a friendly "Tree Farmer" is not located near the school, the Michigan Tree Farm Committee can connect the school with nearby public land that is suitable for a field trip. Michigan Tree Farm can also connect the school with a natural resource professional (forester, biologist, etc.) to support the field trip.

Outdoor Education Curriculum: Field trips to forests are encouraged, but not required, to use lesson plans from standard outdoor education curricula such as Project Learning Tree, Project Wild, Project Wet, the Michigan Environmental Education Curriculum Support (MEECS), etc. Teachers are encouraged, but not required, to be trained in one or more of these outdoor education curricula prior to hosting the field trip to the forest.

- Project Learning Tree - www.MichiganPLT.org

- Project Wild - www.Michigan.gov/MichiganProjectWild

- Project Wet - www.gvsu.edu/wri/education/michigan-project-wet-19.htm

- Michigan Environmental Education Curriculum Support (MEECS) - www.Michigan.gov/deq-meecs

Additional Grants for School Forests: The DNR Forest Stewardship Program provides grants of $\$ 1,000$ plus $\$ 2.50$ per acre up to $\$ 2,500$ per school to develop a Forest Stewardship Plan for a school owned forest. Match is not required. If the grant is not sufficient to cover the costs to hire a professional forester to develop the Forest Stewardship Plan, additional funding may be available from the Michigan Forest Foundation. More information is available at www.Michigan.gov/ForestStewardship or by contacting Mike Smalligan at smalliganm@michigan.gov.

Teacher Workshops: Teachers who are interested in outdoor education are invited to attend summer workshops hosted by the DNR or the Michigan Forest Association. The DNR will be hosting their "Academy of Natural Resources" on July 10-15, 2016 at the Ralph MacMullen Conference Center in Roscommon and "ANR North" on August 8-12 at the Ford Forestry Center in Alberta. More information is available at www.Michigangov/anr. The Michigan Forest Association hosts a weeklong professional development workshop to educate teachers about Michigan's forests at the Ralph MacMullen Conference Center in Roscommon on June 20-24, 2016. More information is available at www.MichiganForests.org. 
Wheels to Woods! - a School to Forest Bus Fund

Application Form

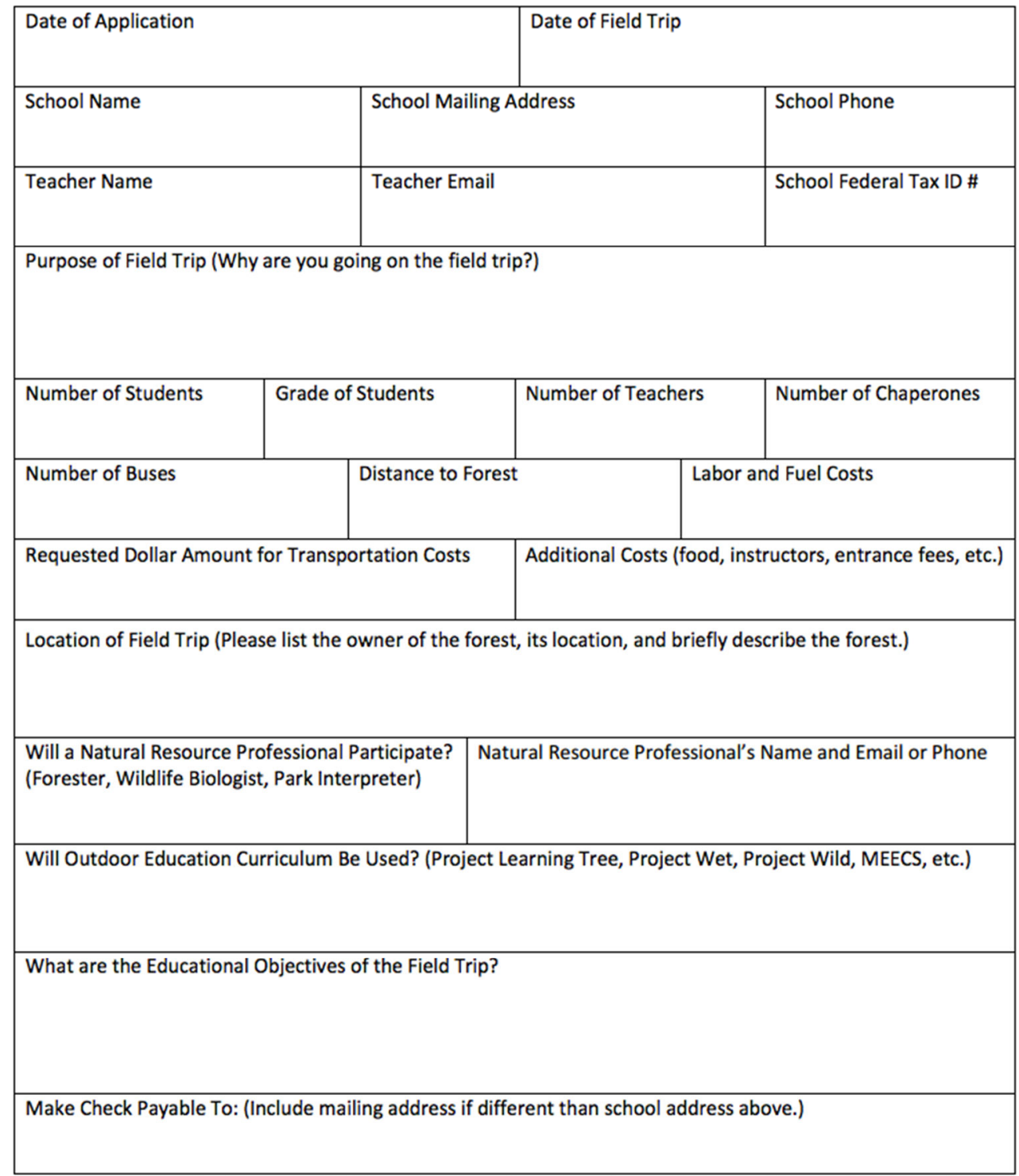

Please send Application to the Michigan Tree Farm Committee by email (docx, pdf) or to the address below. Michigan Tree Farm Committee; 110 West Michigan Avenue, Suite 100, Lansing, MI 48933 Scott Robbins: Office: 517-853-8880; Cell: 906-250-5027; srobbins@michiganforest.com www.TreeFarmSystem.org/School-Forests

3

June 2016 


\section{Wheels to Woods! - a School to Forest Bus Fund}

Post Field Trip Report Form

\begin{tabular}{|c|c|}
\hline Date of Report & Date of the Field Trip \\
\hline School Name & Teacher Name \\
\hline Make Check Payable to: & Send Check to this Address: \\
\hline \multicolumn{2}{|c|}{ Did the field trip to the forest accomplish the intended educational purpose? } \\
\hline \multicolumn{2}{|c|}{ How many students, teachers, and chaperones participated? Did they enjoy the forest visit? } \\
\hline \multicolumn{2}{|c|}{ What were the actual transportation costs? Please attach invoice of the actual costs. } \\
\hline \multicolumn{2}{|c|}{ Was the forest a good location for a school forest field trip? } \\
\hline \multicolumn{2}{|c|}{ Did a natural resource professional participate? Were they helpful? How could they be better? } \\
\hline \multicolumn{2}{|c|}{ Did the outdoor education curriculum fulfill the educational objectives of the field trip? } \\
\hline \multicolumn{2}{|c|}{ Do you have any photos or stories of the field day that you can share with the Michigan Tree Farm Committee? } \\
\hline \multicolumn{2}{|c|}{$\begin{array}{c}\text { Please send Report to the Michigan Tree Farm Committee by email (docx, pdf) or to the address below. } \\
\text { Michigan Tree Farm Committee; } 110 \text { West Michigan Avenue, Suite 100, Lansing, MI } 48933 \\
\text { Scott Robbins: Office: } 517-853-8880 ; \text { Cell: } 906-250-5027 \text {; srobbins@michiganforest.com } \\
\text { Thank you for taking your students out to the forest!! }\end{array}$} \\
\hline www.TreeFarmSystem.org/School-Forests & June 2016 \\
\hline
\end{tabular}




\section{Appendix D: Lesson Plans Developed for This Study Forest Field Trip: Trees Around Us}

Grades 3-5

minutes
Duration: 1 hr 30

Summary: We use many products that come from the various parts of trees. Most students know that wood and paper come from trees, but there are many other products, such as gum and carpeting, that made with parts of trees as well. There are many different species of trees, with many different characteristics. We use these characteristics to help us identify the tree. We can count a trees annual rings to tell how old it is.

Next Generation Science Standards:

3-PS2-1. Cause and effect relationships are routinely identified.

4-PS3-1. Use evidence (e.g., measurements, observations, patterns) to construct an explanation.

4-ESS3-1. Obtain and combine information to describe that energy and fuels are derived from natural resources and their uses affect the environment.

5-PS1-3. Make observations and measurements to identify materials based on their properties.

\section{Performance Objective:}

Students will be able to:

1. Name various products that come from the different parts of trees

2. Identify 3 local trees by looking at the tree characteristics and using a dichotomous key.

3. Determine the age of a tree by counting the annual rings.

\section{Materials:}

- 20 different products that come from trees

- 10 products that do not come from trees

- 10 brown lunch bags or cloth bags

- 10 clipboards and pencils (one for each group of students)

- dichotomous key (one for each student)

- 15 branches from trees listed on the dichotomous key

- 10 tree cookies from various tree species and of various ages

- 2 increment borers 


\section{Lesson Outline}

\section{Activity 1- Products that come from trees (40 minutes)}

(Adapted from the Project Learning Tree Activity 13: We All Need Trees. Pages 6568.)

Introduction (5 min)

Briefly discuss the various parts of a tree and have students name things that come from those various parts. Let the students lead the discussion with naming the parts and products; don't give them any additional ideas at this time.

What's in the bag? (5 min)

Pass out one bag to each group of three students. Inside the bag will be three objects, two that come from trees and one that doesn't. Give each group about 5 minutes to look at their objects and determine what object doesn't come from trees and which two do. Have them try to figure out what part of the tree the objects come from.

What's in Your bag? (30 min)

Give each group of students a turn to show their objects to the rest of the class and as a whole group determine where the objects come from. Write the object and answers on a dry erase board or easel paper and at this time explain to the whole group more about the product and what part of tree it comes from.

\section{Activity 2- What Trees are in This Forest? (30 min)}

(Adapted from the Project Learning Tree Activity 68: Name that Tree. Pages 65-68.)

Introduction (5 min)

Discuss the various tree characteristics that could be used to identify trees (leaves, tree shape, bark, fruit, etc) Show students examples of the different characteristics

How to Use a Dichotomous Key (10 min)

Pass out a dichotomous key to each student. Practice using it to identify together a white ash branch and blue spruce branch.

Tree ID (15 min)

Have students work in pairs and give each pair a tree branch from one of the trees listed on the dichotomous key (cedar, balsam fir, white pine, red pine, red oak, sugar maple). Give them about 10 minutes to use the key to identify the branch they were given. If they finish quickly they can switch branches with another group that has finished. Have all of the pairs with the same branches group together. They can return their branches to the instructor when that tree name is called. 


\section{Activity 3- Telling Tree Age (20 min)}

(Adapted from the Project Learning Tree Activity 76: Tree Cookies. Pages 327-329.)

Introduction (5 min)

Ask the students if they know how to tell how old a tree is. Hold up 2 tree cookies and have them choose which one they think is the oldest. Show them the annual rings and how to count them to tell the age of a tree. Show students how the distance between the rings varies depending on the amount of growth that year. Ask students what factors might influence the amount a tree grows each year.

Counting Annual Rings (5 min)

Pass out a tree cookie to each pair of students. Have them count the rings to determine how old the tree is. Have them determine which year was the smallest growth and which was the largest.

Using an Increment Borer (10 min) Ask students if it is possible to tell how old a tree is without cutting it down. Show the students an increment borer and bore a tree letting the students each have a turn spinning the borer. 


\section{Appendix E: Permission Slip Required for Student Participation}

May 13, 2016

Dear Parent or Guardian:

I am a graduate student in science education at Michigan Technological University and am conducting a research study focused on assessing outdoor forest field trip programming. Your child's teacher has signed up to participate in an outdoor forest field trip, which is a part of my research study.

The field trip will be on Friday, May $20^{\text {th }}$ ( $3^{\text {rd }}$ grade $)$ and Monday, May $23^{\text {rd }}\left(4^{\text {th }}\right.$ and $5^{\text {th }}$ grade $)$ at a forested area near Lost Lake.

Along with participating in the field trip, the students will complete a short pre and post questionnaire, which will be administered during the field trip. Your child's name will not be on the paper when they are turned into me. The data collected from the questionnaires will be used to assess the impacts of the outdoor forest field trip experience, but the no names (school, teacher, student) will be used in my report.

Please indicate in the space below whether you grant permission for your child to participate in this outdoor field trip.

Sincerely,

Michelle Miller

Graduate Student

Michigan Technological University

michellem@mtu.edu

Signature of Parent/Guardian

Printed Parent/Guardian Name

Printed Name of Child

Date 
Appendix F: Pre- and Posttest, Grading Rubric and Test Samples

School Grade Class Student \#

\section{Forest Field Trip Questionnaire: Trees Around Us PRETEST}

Question 1: Circle the products on the list below that come from trees. If you circled the product, write next to it what part of a tree it comes from.

Product we use

Part of the Tree it comes from

CHOCOLATE

APPLESAUCE

LUMBER FOR BUILDING

RAYON

CHEWING GUM

CINNAMON

MAGAZINES

OLIVE OIL

RUBBER

CLEANING FLUIDS

Question 2: How can you tell the difference between a red pine and a white pine?

Question 3: What type of branching is this?

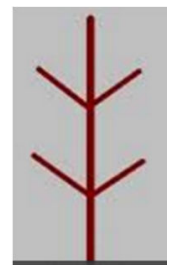

Question 4: What is an increment borer? 


\section{Forest Field Trip Questionnaire: Trees Around Us POSTTEST}

Question 1: Circle the products on the list below that come from trees. If you circled the product, write next to it what part of a tree it comes from.

Product we use

Part of the Tree it comes from

CHOCOLATE

APPLESAUCE

LUMBER FOR BUILDING

RAYON

CHEWING GUM

CINNAMON

MAGAZINES

OLIVE OIL

RUBBER

CLEANING FLUIDS

Question 2: How can you tell the difference between a red pine and a white pine?

Question 3: What type of branching is this?

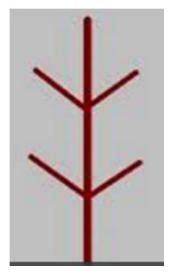

Question 4: What is an increment borer?

Would you like to do more outdoor lessons like you did today? Yes No Write a sentence explaining why or why not. 


\section{Forest Field Trip Questionnaire: Trees Around Us- EXEMPLERY PRODUCT}

Question 1: Circle the products on the list below that come from trees. If you circled the product, write next to it what part of a tree it comes from.

Product we use

\section{CHOCOLATE}

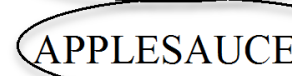

Part of the Tree it comes from fruit or nut fruit trunk or wood wood or cellulose leaves or sap bark wood, pulp or cellulose fruit or nut

OLIVE OIL sap

$$
\text { RUBBER }
$$

CLEANING FLUIDS sap, fruit or leaves

Question 2: How can you tell the difference between a red pine and a white pine?

A red pine has two needles per bundle and a white pine has five needles per bundle.

Question 3: What type of branching is this? opposite

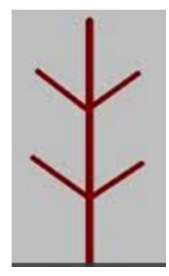

Question 4: What is an increment borer?

Option 1: An increment borer is a tool used to determine the age of a tree without cutting it down.

Option 2: An increment borer is a tool used to core a tree to determine its age. 


\section{3rd pretest}

School

Grade

Class

Student \#

\section{Forest Field Trip Questionnaire: Trees Around Us}

Question 1: Circle the products on the list below that come from trees. If you circled the product, write next to it what part of a tree it comes from.

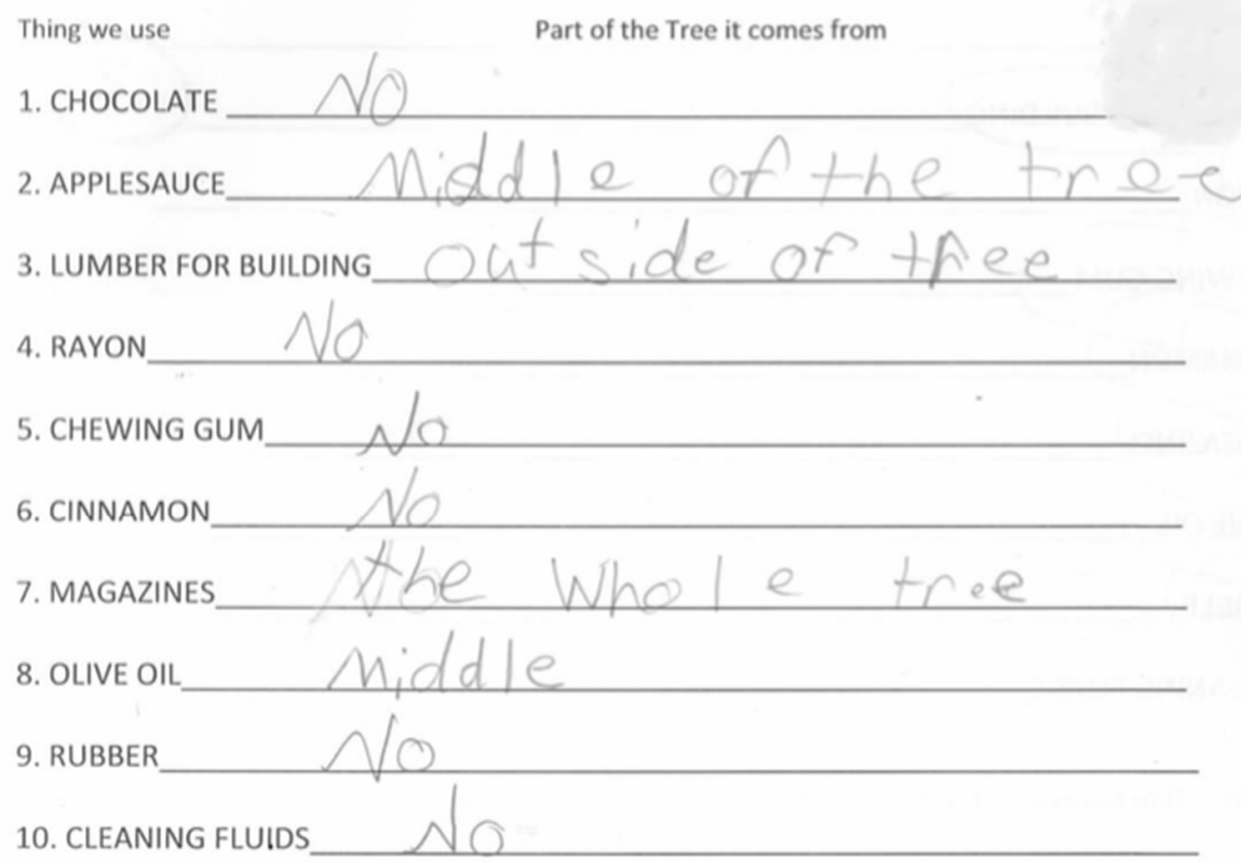

Question 2: How can you tell the difference between a red pine and a white pine?

Question 3: What type of branching is this?

Question 4: What is an increment borer?

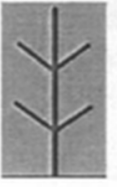


School Grade Class Student

Question 1: Circle the products on the list below that come from trees. If you circled the product, write next to it what part of a tree it comes from.

Thing we use

1. CHOCOLATE

2. APPLESAUCE

3. LUMBER FOR BUILDING

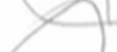

4. RAYON

5. CHEWING GUM

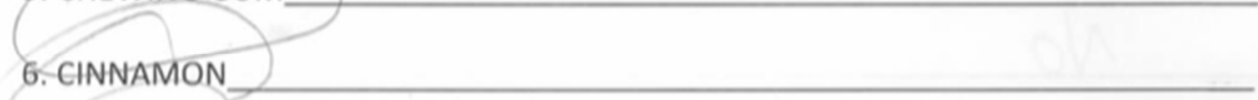

7. MAGAZINES

8. OLIVE OIL

9. RUBBER

\section{CLEANING FLUIDS}

Question 2: How can you tell the difference between a red pine and a white pine?

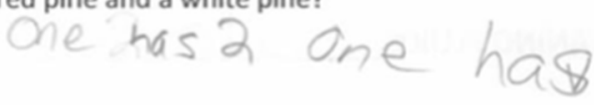

Question 3: What type of branching is this?
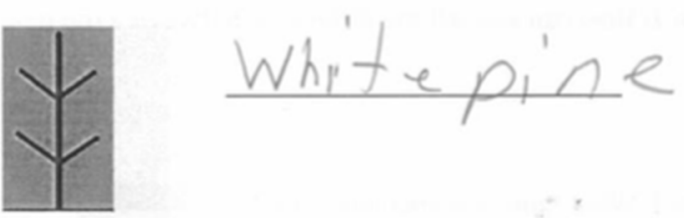

Question 4: What is an increment borer?

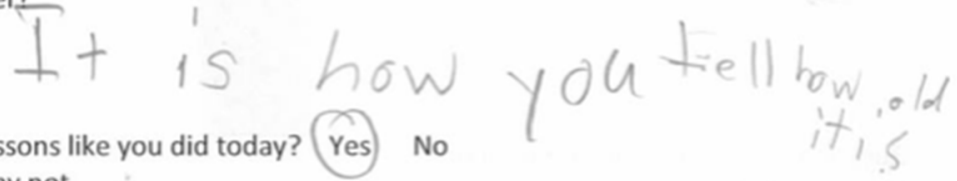

Would you like to do more outdoor lessons like you did today? (Yes) No Write a sentence explaining why or why not.

$$
\text { It helped me nothe outdois }
$$




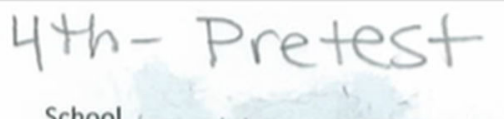

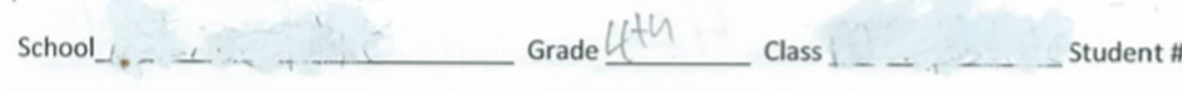

\section{Forest Field Trip Questionnaire: Trees Around Us}

Question 1: Circle the products on the list below that come from trees. If you circled the product, write next to it what part of a tree it comes from.

Thing we use

Part of the Tree it comes from

1. CHOCOLATE

2. APPLESAUCE

3. LUMBER FOR BUILDING

4. RAYON

5. CHEWING GUM midd le

6. CINNAMON

7. MAGAZINES

8. OLIVE OIL

9. RUBBER

10. CLEANING FLUIDS

Question 2: How can you tell the difference between a red pine and a white pine?

Question 3: What type of branching is this?

Question 4: What is an increment borer?

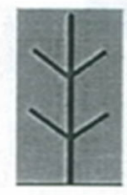




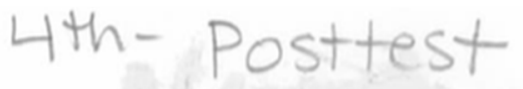

School _... Grade $4+6$ Class. Student \# ${ }_{-,}$,

Question 1: Circle the products on the list below that come from trees. If you circled the product, write next to it what part of a tree it comes from.

Thing we use

Part of the Tree it comes from

1. CHOCOLATE

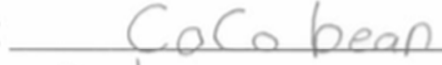

2. APPLESAUCE ffuit

3. LUMBER FOR BUILDING_flunch

4. RAYON

5. CHEWING GUM

6. CINNAMONbair

7. MAGAZINES I ruAC b

8. OLIVE OIL ALN

9. RUBBER

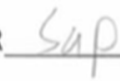

10. CLEANING FLUIDS

Question 2: How can you tell the difference between a red pine and a white pine?

$$
\text { ed. has } 2 \text { paits und white is } 5 \text { Pals }
$$

Question 3: What type of branching is this?

Question 4: What is an increment borer?
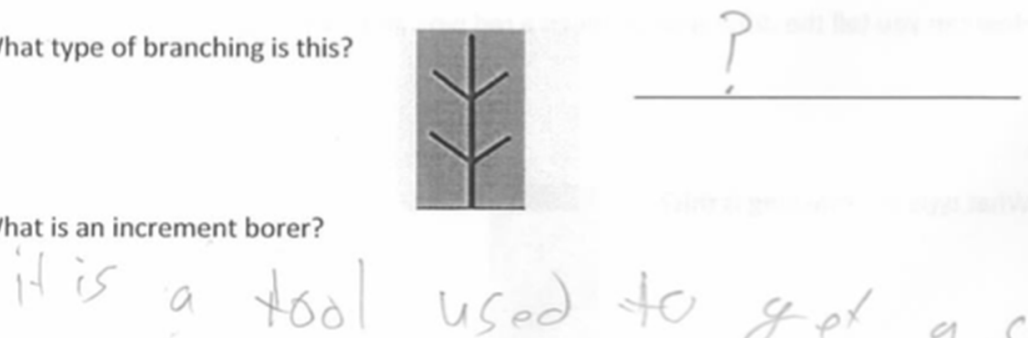

$$
\text { USed }
$$

Would you like to do more outdoor lessons like you did today? Yes Write a sentence explaining why or why not.

No

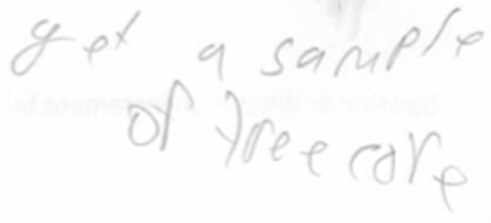




\section{Forest Field Trip Questionnaire: Trees Around Us}

Question 1: Circle the products on the list below that come from trees. If you circled the product, write next to it what part of a tree it comes from.

Thing we use Part of the Tree it comes from

1. CHOCOLATE coco trees

2. APPLESAUCE

apple trees

3. LUMBER FOR BUILDING wool trunks

4. RAYON

5. CHEWING GUM sap

6. CINNAMON

7. MAGAZINES Bark

8. OLIVE OIL

9. RUBBER

10. CLEANING FLUIIDS

Question 2: How can you tell the difference between a red pine and a white pine?

Question 3: What type of branching is this?
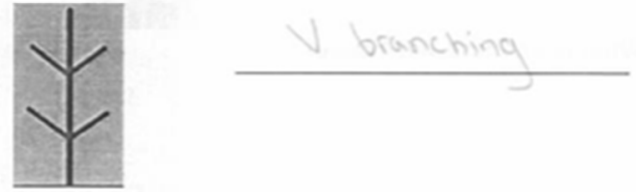

Question 4: What is an increment borer? 
5th Posttest

School

Grade $5^{+h}$

Class

Student \#

Question 1: Circle the products on the list below that come from trees. If you circled the product, write next to it what part of a tree it comes from.

Thing we use

Part of the Tree it comes from

1. CHOCOLATE coco trees

2. APPLESAUCE apple trees

3. LUMBER FOR BUILDING wood/ frunk

4. RAYON trun is I bark

5. CHEWING GUM haves / sap

6. CINNAMON bark

7. MAGAZINES trunk/ Pulp

8. OLIVE OIL olive trees

9. RUBBER Rulp

10. CLEANING FLUIDS oils and sent from CRe

Question 2: How can you tell the difference between a red pine and a white pine?

$$
\begin{aligned}
& \text { White pine has } 5 \text { needles in a bounch } \\
& \text { Red Pin has } 3 \text { needles, in a bunch }
\end{aligned}
$$

Question 3: What type of branching is this?

Question 4: What is an increment borer?

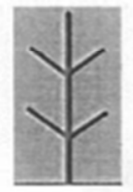

th a thing

cutica it dawn.

Would you like to do more outdoor lessons like you did today? Yes No Write a sentence explaining why or why not.

$$
\text { becave I }
$$$$
\text { then indoors. }
$$

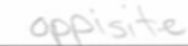

$\infty \mathrm{C}$

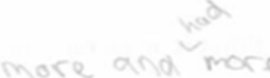

P

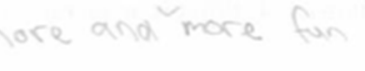


Appendix G: Teacher Survey Administered by Google Forms

\section{Spring Forest Field Trip Teacher Survey}

Please submit feedback regarding the spring forest field trip you participated in with your class and field trips in general.

\section{School}

2. On average, how many field trips requiring bus transportation does your class attend each school year?

3. How many of these field trips involve a visit to a forested area?

4 What prevents you from taking your students on a forest field trip?

Scheduling issues

Transportation costs

Managing students in an outdoor setting

Environmental Science is not my strength

Dealing with mosquitos, ticks or unfavorable weather

The school administration does not support these opportunities Other:

\section{Explain}

5 Are you more likely to take your students on a field trip if the transportation costs are reimbursed?

Yes

No

\section{Explain}


6. Are you more likely to take your students on a field trip if a natural resource professional is there to lead the activities?

Yes

No

\section{Explain}

7. What did you like MOST about the 2016 spring field trip you participated in?

8. What did you like LEAST about the 2016 spring field trip you participated in? 